\title{
Additions to the latest Paleocene Buckman Hollow local fauna, Chappo Member of the Wasatch Formation, Lincoln County, southwestern Wyoming
}

\author{
Patricia A. Holroyd and Brian D. Rankin
}

\begin{abstract}
With few notable exceptions, mammalian faunas from the latest Paleocene of North America (Clarkforkian North American Land Mammal Age, approximately 57 to $55.7 \mathrm{Ma}$ ) are poorly known, with the vast majority recovered from a single area, the Bighorn Basin of northwestern Wyoming. Comparably aged faunas elsewhere are few. Here we describe new material, including several previously undocumented species, from the Buckman Hollow local fauna from the Green River Basin of southwestern Wyoming. Newly documented occurrences include the multituberculate Neoliotomus conventus, the oxyaenid creodont Dipsalidictis, and a rare phenacodontid condylarth Ectocion cf. E. major. Although sparse, these additions offer the opportunity to reevaluate biostratigraphic and biogeographic patterns observed among latest Paleocene faunas, which include differing mammalian co-occurrence patterns in these more southerly faunas than seen in the Bighorn Basin.
\end{abstract}

Patricia A. Holroyd. Museum of Paleontology, University of California, 1101 Valley Life Sciences Building, Berkeley, California 94720, United States. pholroyd@berkeley.edu

Brian D. Rankin. Department of Biological Sciences, University of Calgary, 2500 University Ave NW,

Calgary, Alberta T2N 1N4, Canada. bdrankin@ucalgary.ca

Keywords: Paleocene; Clarkforkian; mammalia; biostratigraphy; biogeography

\section{INTRODUCTION}

Latest Paleocene (Clarkforkian North American Land Mammal Age [NALMA]) mammalian faunas outside that of the combined Bighorn and Clarks Fork Basins of northwestern Wyoming are comparatively few. Other reports from sedimentary basins within Wyoming include those from the
Buckman Hollow fauna from the Green River Basin (Gazin, 1942, 1956; Dorr and Gingerich, 1980), the Togwotee Pass area of the Purdy Basin, including the Red Creek locality (McKenna, 1980; Rose, 1981), Big Multi Quarry in the Washakie Basin (Wilf et al., 1998; Dawson and Beard, 1996; Chester and Beard, 2012), and Mark's Locality in the Great 


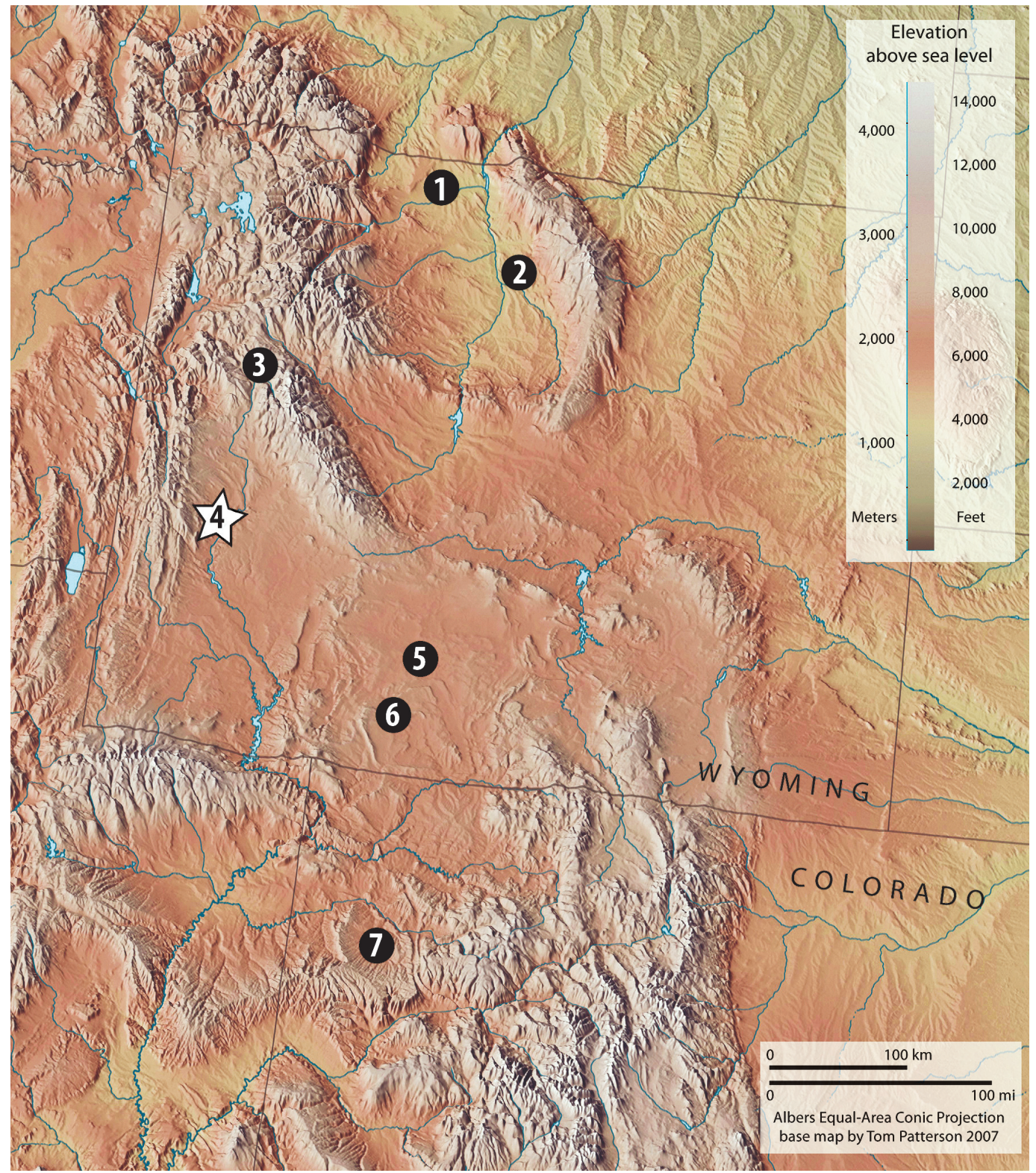

FIGURE 1. Map showing the locations and spatial relationships of documented mammal-bearing fossil assemblages assigned to the late Paleocene Clarkforkian NALMA: 1, Clark's Fork Basin; 2, Bighorn Basin; 3, Togwotee Pass; 4, Buckman Hollow; 5, Mark's Locality; 6, Big Multi Quarry; 7, Piceance Basin.

Divide Basin (Anemone and Dirks, 2009). Clarkforkian localities are also known from the Debeque Formation of the Piceance Creek Basin in Colorado (Patterson, 1933, 1934, 1937, 1939; Patterson and West, 1973; Kihm, 1984; Lucas, 1998; Burger and Honey, 2008; Burger, 2012) (Figure 1). Among these localities outside of northwestern Wyoming, only the Buckman Hollow mammals have been previously described nearly in their entirety. Most of these other faunas are known primarily from faunal lists, although specimens from many have been included in focused systematic works (Patterson, 1933, 1934, 1937, 1939; Burger and Honey, 2008; Thewissen, 1990; Chester and Beard, 2012). Given the rarity of late Paleocene mammal fossils outside the Bighorn Basin, it is important to better document the taxa and specimens that form the basis for the characterization of local faunas used to establish the geographic ranges of late Paleocene taxa. Here we report new occurrences and additional specimens of previously reported mammals from the Buckman Hollow fauna of the Chappo Member of the Wasatch Formation of Lincoln County, Wyoming. 
Gazin $(1942,1956)$ was the first to describe a small assemblage of specimens from several closely spaced localities in Buckman Hollow from rocks he termed the Almy Formation. Oriel (1962) revised the stratigraphic nomenclature and indicated the rocks yielding the Buckman Hollow fauna as a secondary reference section of the newly named Chappo Member of the Wasatch Formation. Later, Dorr and Gingerich (1980) confirmed the stratigraphic distinctiveness of these strata and noted at least five vertebrate producing horizons exposed there in a 108.75 meter thick section; notably, these authors did not explicitly attempt to reconcile these localities with the original field collections by Gazin and colleagues. Gazin's field notes (on file and accessible at USNM) indicate that five collecting areas within Buckman Hollow were recognized but only informal descriptions of these areas, based principally on topography and quarter-quarter sections, were provided. Fieldwork by one of us (PAH) and J.H. Hutchison recovered additional specimens from the area at nine geographically close but distinct locations. Three of these (UCMP localities V96274, V96278, and V96291) produced mammalian fossils diagnostic to genus and/or species level. The others (UCMP localities V96277, V96284, V96285, V96286, V96288, and V96289) lacked clearly diagnostic mammalian fossils, although several diagnostic specimens of the platysternid turtle Cardichelyon (Hutchison, 2013) were found (UCMP V96274/ 173398, V96278/173491, V96284/173522, V96285/218741, V96288/218744, V96290/ 218740 , and V96291/173517). Some of these locations are almost certainly the same as Gazin's original locales; comparison of these with his notes indicates all the collections were made in the same approximately 0.6 square kilometer area, and vertebrate fossils were primarily found in the lower 30 meters of the local section. However, precise locality concordances across the collections are impractical and beyond the level of available stratigraphic detail, particularly since most of the fossils were recovered as surface float. Locality data are on file at each institution.

Expressly excluded here are specimens collected by C.L. Gazin, F.L. Pierce, and S. Oriel at a locality referred to in Gazin's field notes and on many USNM tags as "new Buckman Hollow faunal locality" and by Gazin's field number 29-61. Based on the coordinates in Gazin's notes and faunal comparisons, these specimens are from the locality that was later recognized as the Chappo Type Locality and assigned to the older Paleocene Tiffa- nian NALMA, Ti3 subage (Dorr and Gingerich, 1980; Gunnell, 1994). Thewissen (1990) inadvertently reported some of these specimens as uncataloged Clarkforkian phenacodontids under "USNM field number 29-61."

\section{MATERIAL AND METHODS}

Dental nomenclature. The dental terminology used here generally follows that of Van Valen (1966), with some modification provided by Szalay (1969). Upper case letters specify teeth of the upper dentition, and lower case letters indicate those of the lower dentition. Dental measurements were taken using an ocular micrometer for UCMP specimens and digital calipers for USNM specimens. Abbreviations of the measurements and statistics are as follows: $L=$ maximum anteroposterior length of tooth crown; $W=$ maximum labiolingual width of tooth crown; TaW = maximum labiolingual width of talonid; TrW = maximum labiolingual width of trigonid; $n=$ sample size; $S D=$ standard deviation; SE = standard error.

Institutional abbreviations. UCMP, University of California Museum of Paleontology, Berkeley, California; UM, University of Michigan Museum of Paleontology, Ann Arbor, Michigan; USNM, United States National Museum, Washington, District of Columbia.

\section{SYSTEMATIC PALAEONTOLOGY}

\author{
Class MAMMALIA Linnaeus, 1758 \\ Subclass ALLOTHERIA Marsh, 1880 \\ Order MULTITUBERCULATA Cope, 1884 \\ Suborder CIMOLODONTA McKenna, 1975 \\ Superfamily PTILODONTOIDEA (Sloan and Van \\ Valen, 1965) \\ Family incertae sedis \\ Genus NEOLIOTOMUS Jepsen, 1930 \\ Neoliotomus conventus Jepsen, 1930
}

Figure 2.1-3

Newly referred material. UCMP 170782, left i1 (Figure 2.1-3) from UCMP locality V96278.

Descriptions and remarks. Thorough descriptions and figures of the dentition of the enigmatic and comparatively large multituberculate Neoliotomus have previously been provided by Granger and Simpson (1928), Jepsen (1930), McKenna (1960), and Krause (1982). The referred specimen most closely resembles the fragmentary i1 in the holotype of $N$. conventus (YPM-PU 13297) from the Paint Creek locality (Jepsen, 1930) and the i1 of N. ultimatus (Granger and Simpson, 1928) figured by Krause (1982). The comparatively large, 


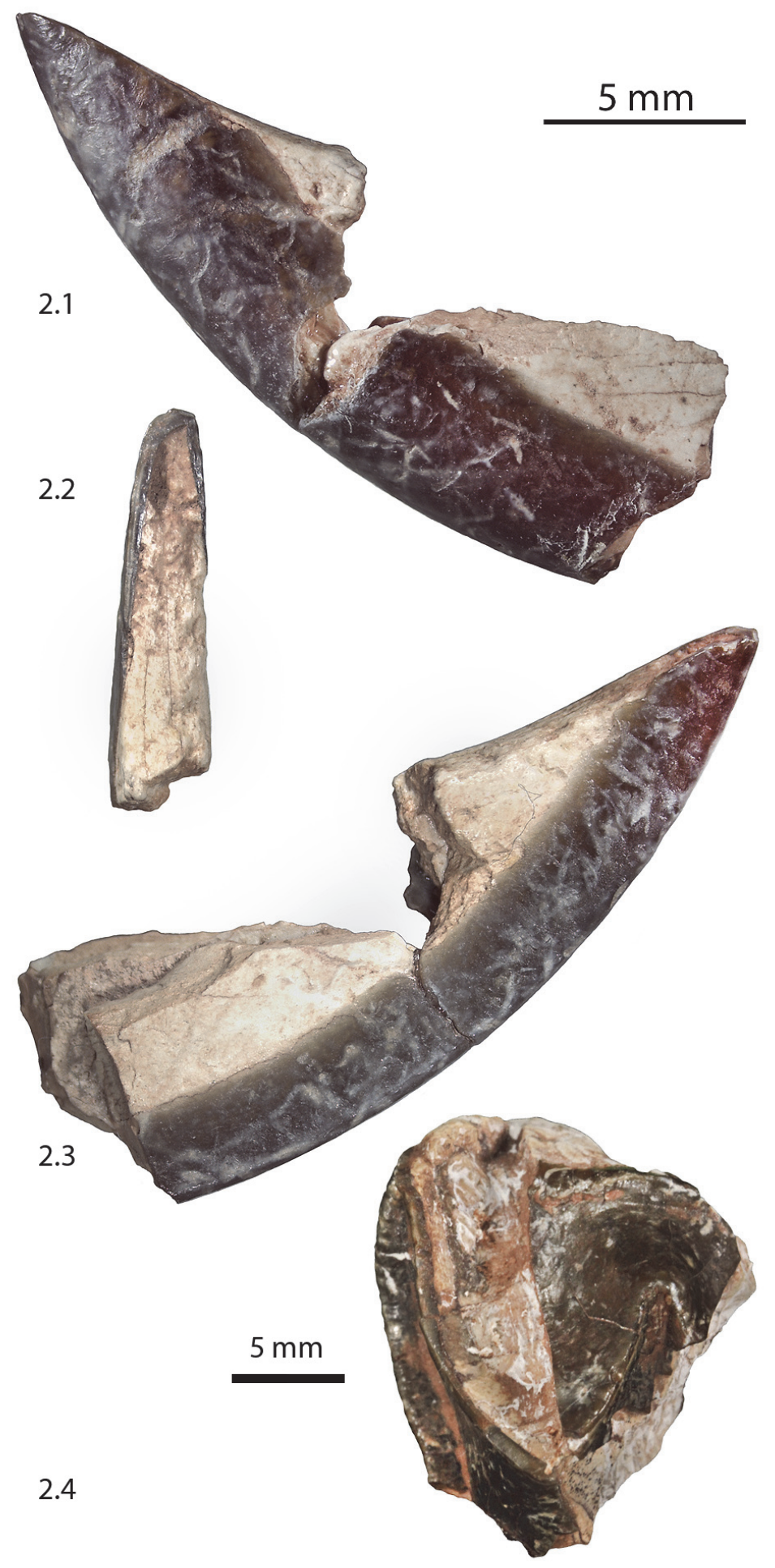

FIGURE 2. Multituberculata and Cimolesta. 2.1-2.3, UCMP 170782, Neoliotomus conventus, left i1 in lateral (2.1), occlusal (2.2), and lingual (2.3) views; 2.4, UCMP 173399, Barylambda faberi, left M1 fragment. 
procumbent crown is robust and mediolaterally compressed, and the enamel is restricted to the ventral, ventrolabial, and midline surfaces. Krause $(1980,1982)$ cited the larger size of $N$. conventus as one of the few characters that distinguishes it from $N$. ultimatus, and further suggested that the two species are part of the same evolutionary lineage ranging from the early late Tiffanian (Ti5) to the middle Wasatchian (Wa4), with $N$. conventus known only from localities older than the Wasatchian. Although documented by a single specimen, the occurrence of $N$. conventus notably represents only the second record of a multituberculate in the Buckman Hollow local fauna (see description of Prochetodon sp. from the assemblage in Krause, 1987 ) and documents the presence of a very large multituberculate lineage in the area. This occurrence is only the third report of the genus and species outside the Bighorn Basin (see Wilf et al., 1998; Burger, 2012).

\section{Subclass THERIA Parker and Haswell, 1897} Infraclass EUTHERIA Gill, 1872

Grandorder FERAE Linnaeus, 1758

Order CIMOLESTA McKenna, 1975

Suborder PANTODONTA Cope, 1873a

Family PANTOLAMBDIDAE Cope, 1883

Genus BARYLAMBDA Patterson, 1937

Barylambda faberi (Patterson, 1937)

Figure 2.4

Newly referred material. UCMP 173399 , partial left M1 (Figure 2.4) from UCMP locality V96274.

Descriptions and remarks. UCMP 173399 is the incomplete anterior half of an M1 that shares a number of features with that of the pantolambdid pantodont Barylambda faberi: the parastylar lobe extends only slightly anterolabially, the ectoflexus is shallow, the preparacrista is tall and curves anterolabially from the apex of the paracone, the centrocrista is deflected labially, and the paracingulum forms a narrow shelf anterior to the paracone (Gingerich and Childress, 1983). The referred specimen, though incomplete, is clearly larger than comparable teeth of the Tiffanian Haplolambda quinni Patterson, 1939 and Ignatiolambda barnesi Simons, 1960. Dorr and Gingerich (1980) previously assigned a single lower molar from Buckman Hollow (UM 71339) to cf. Titanoides primaevus(?), but this identification was later emended to Barylambda faberi (Gingerich and Childress, 1983).

Order CREODONTA Cope, 1875

Family OXYAENIDAE Cope, 1877

Subfamily OXYAENINAE Cope, 1877

Genus DIPSALIDICTIS Matthew, 1915a
Dipsalidictis krausei Gunnell and Gingerich, 1991 Figure 3

Newly referred material. UCMP 173490 , left $\mathrm{m} 2$ $(\mathrm{m} 2, \mathrm{~L}=12.3 \mathrm{~mm}, \mathrm{TrW}=7.8 \mathrm{~mm}, \mathrm{TaW}=6.4 \mathrm{~mm})$ from UCMP locality V96291 (Figure 3.1-3).

Description. The trigonid of the referred $\mathrm{m} 2$ is tall and subtriangular in occlusal outline. The protoconid is damaged and the apex of this cusp has been broken off; however, based on the relative size of the base, the protoconid likely would have been the tallest of the trigonid cusps. The paraconid and metaconid are subequal in size and subtriangular in cross section, with the internal walls inflated; the paraconid is slightly taller than the metaconid, and the apex of this cusp is displaced internally from the lingual margin of the crown. Based on what remains of the paracristid and protocristid, both crests were robust but distinct carnassial notches were not present. As in the holotype of Dipsalidictis krausei (UM 69331), the talonid is well developed but narrower than the trigonid, and the talonid basin slopes gently lingually to the narrow talonid notch (see Gunnell and Gingerich, 1991). The principal talonid cusps are inflated and appear to have been nearly equal in height and size, although the enamel is damaged in areas and makes the original dimensions of these cusps impossible to determine; small but distinct notches are developed between these cusps. The thick cristid obliqua contacts the postvallid surface slightly labial to the midline of the trigonid, and a small notch is present midway along the length of this crest. A welldefined precingulid originates high on the anterior surface of the trigonid, ventral to the paraconid, but descends steeply as it runs transversely towards the base of the trigonid beneath the protoconid. A short, robust crest runs anteriorly from the apex of the paracone and contacts the precingulid.

Remarks. Although never particularly abundant, oxyaenid creodonts are relatively well represented in the latest Paleocene and earliest Eocene of North America (Gunnell and Gingerich, 1991). Dipsalidictis krausei is described from the Clarkforkian of the Bighorn Basin of northwestern Wyoming (Gunnell and Gingerich, 1991) and reported from the Purdy Basin (McKenna (1980) as Oxyaena spp. in faunal lists and subsequently transferred back to Dipsalidictis by Gunnell and Gingerich (1991) by reference to the published faunal list). The referred $\mathrm{m} 2$ from the Buckman Hollow local fauna is virtually identical to comparable teeth of $D$. krausei from the type locality (Krause Quarry, UM SC-195): the trigonid is comparatively short, the metaconid is robust and subequal to the 

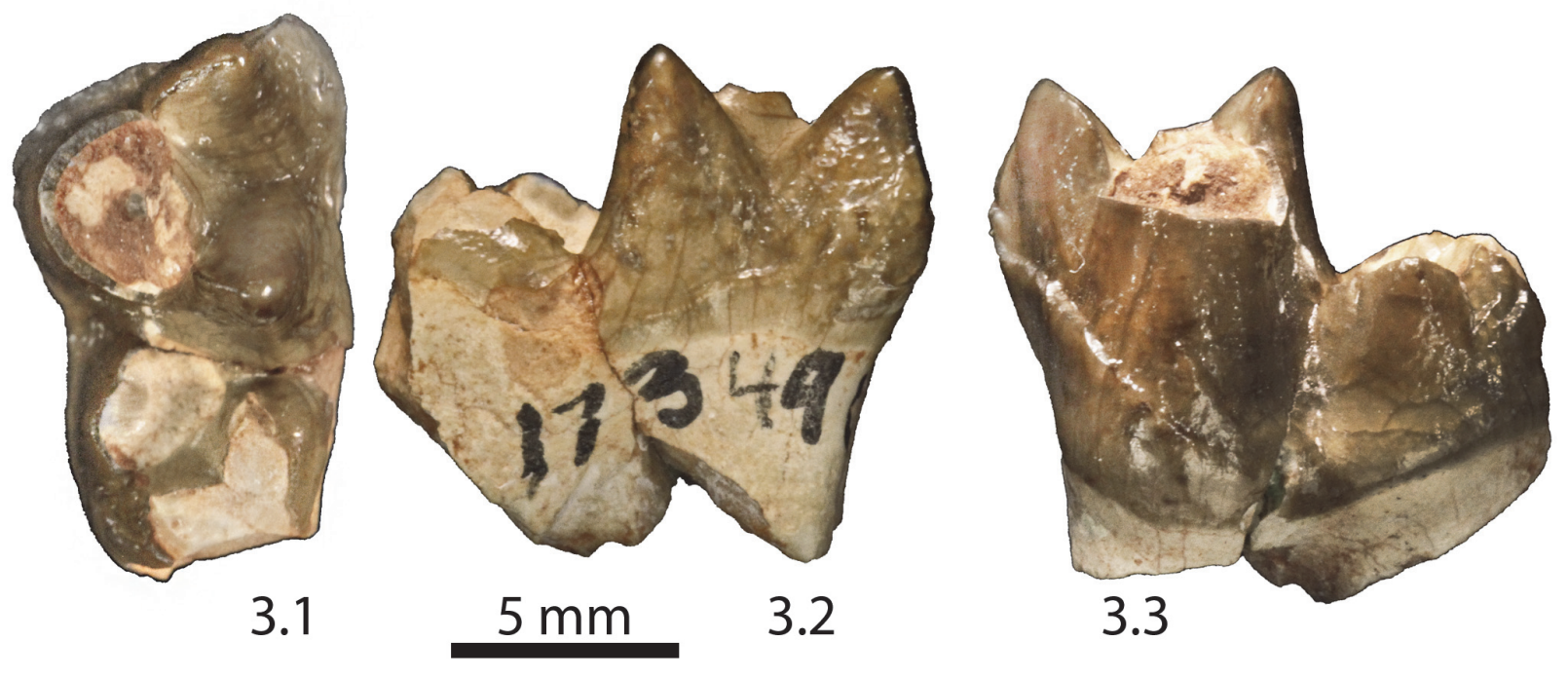

FIGURE 3. Creodonta. UCMP 173490, Dipsalidictis krausei left $\mathrm{m} 2$, in occlusal (3.1), lingual (3.2), and lateral (3.3) views.

paraconid, the talonid is narrower than the trigonid, and the principal talonid cusps are well developed. The discovery of $D$. krausei from the Buckman Hollow represents the first convincing report of this species outside of the Bighorn Basin.

Grandorder ARCHONTA Gregory, 1910 Order PRIMATES Linnaeus, 1758

Superfamily PLESIADAPOIDEA Trouessart, 1897

Family PLESIADAPIDAE Trouessart, 1897

Genus PLESIADAPIS Gervais, 1877

Plesiadapis dubius (Matthew, 1915b)

Figures 4, 5

Newly referred material. UCMP 173400 , incomplete right dentary with $\mathrm{p} 4$ and $\mathrm{m} 1(\mathrm{p} 4, \mathrm{~L}=2.8 \mathrm{~mm}$, $\mathrm{W}=2.4 \mathrm{~mm} ; \mathrm{m} 1, \mathrm{~L}=3.3 \mathrm{~mm} ; \mathrm{TrW}=2.5 \mathrm{~mm} ; \mathrm{TaW}$ $=2.6 \mathrm{~mm}$ ) from UCMP locality V96274 (Figures 4.1-3, 5.2).

Descriptions. UCMP 173400 is a dentary preserving $\mathrm{p} 4$ and $\mathrm{m} 1$. The subquadrate crown of $\mathrm{p} 4$ is premolariform and dominated by a tall, inflated protoconid, with an anteriorly sloping posterior wall, and a short, low talonid. A well-defined paracristid extends anteriorly and slightly labially from the apex of the protoconid but abruptly turns lingually near the base of the cusp before contacting the distinct anterior cingulid. Two additional well-developed crests descend posterolabially and posterolingually from the apex of the protoconid, and define the corresponding labial and lingual borders of the postvallid surface. The posterior rim of the talonid is elevated to form an elongate, transversely oriented ridge; the hypoconid and hypoconulid occur as small but distinct swellings near the posterolabial and posterolingual extremities of this ridge, respectively. A well-defined cristid obliqua runs anterolingually from the hypoconid and continues a short distance on the postvallid surface, while a much fainter entocristid runs anteriorly from the posterolingual corner of the crown to meet the crest descending posterolingually from the protoconid apex. The p4 is similar in shape to that of USNM 16696 (Figure 5.1) but is slightly broader and exhibits less wear.

The $\mathrm{m} 1$ is low crowned and slightly shorter than $\mathrm{p} 4$. The trigonid is narrower than the talonid and, as in the p4, the postvallid surface slopes anteriorly. The principal trigonid cusps are bunodont, with the protoconid being the largest and tallest, followed closely by the metaconid, and the smaller, lower paraconid. The paraconid is inset from the labial margin of the crown and positioned just anterior to the level of the protoconid, while the metaconid is positioned slightly posterior to the level of the protoconid. A long, anteriorly arcuate paracristid extends between the apices of the protoconid and paraconid, and forms a narrow anterior shelf; a shallowly notched protocristid connects the protoconid and metaconid. There is no development of a metacristid, in contrast to the more marked development of this crest on both the first and second molars of the previously-referred USNM 20787 (Figure 5.3, the holotype of the synonymized Plesiadapis? pearcei Gazin, 1956). The massive hypoconid is the largest talonid cusp, and the shallow talonid basin slopes gently anterolingually from the apex of this cusp. A robust cristid obliqua extends anterolingually from the apex of 

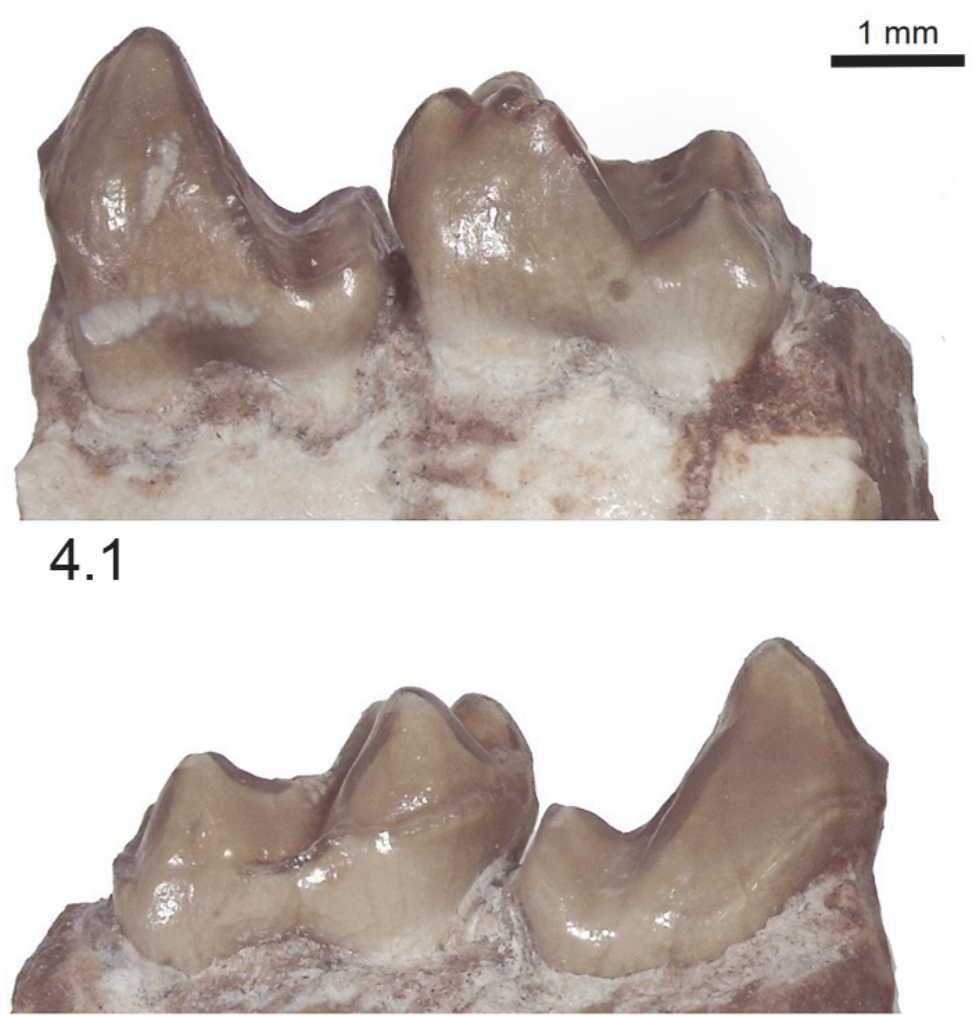

4.2

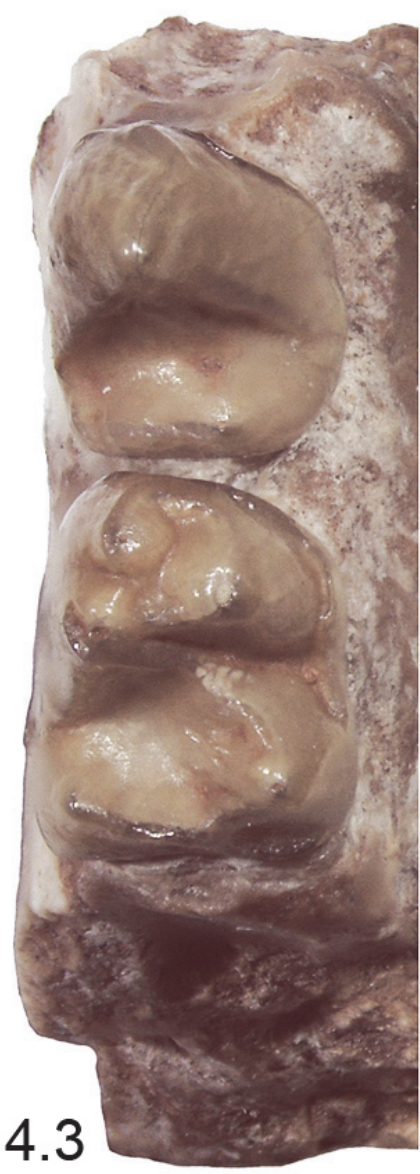

FIGURE 4. Primates. UCMP 173400, Plesiadapis dubius, in lateral (4.1), lingual (4.2), and occlusal (4.3) views.

the hypoconid and contacts the postvallid surface low and beneath the midline of the trigonid before continuing to the metaconid apex. The talonid basin is mildly crenulate, similar to the condition in USNM 16696, and characteristic for $P$. dubius, although this feature is generally expressed more strongly on the $\mathrm{m} 2$ and $\mathrm{m} 3$. The entoconid is positioned on the posterolingual corner of the talonid basin and slightly lower than the hypoconid; the hypoconulid is fully incorporated into a low postcristid that extends between the apices of the hypoconid and entoconid. The moderately developed anterior cingulid wraps around the anterolabial corner of the crown and joins with the ectocingulid; this crest continues low on the labial margin of the crown but fades posterior to the hypoflexid.

Remarks. Gazin $(1942,1956)$ first reported specimens of Plesiadapis from the Buckman Hollow local fauna and assigned these to the new species, Plesiadapis? pearcei (holotype, USNM 20787) and
P. rubeyi (holotype, USNM 16696). Both species were subsequently synonymized with $P$. dubius (see synonymies by Gingerich (1976) for P.? pearcei and Dorr and Gingerich (1980) for $P$. rubeyi). The newly referred dentary is morphologically consistent with those previously assigned to $P$. dubius (Gingerich, 1976; Burger and Honey, 2008) and shows a first molar pattern that is more consistent with $P$. dubius known from elsewhere, in contrast to the somewhat less bulbous cusps and strong metastylid of USNM 20787. Specimens of $P$. dubius are considerably smaller than comparable teeth of $P$. cookei, the only other plesiadapid known from the local fauna (see Gazin, 1942, 1956; Gingerich, 1976; Dorr and Gingerich, 1980).

Grandorder UNGULATA Linnaeus, 1766

Order DINOCERATA Marsh, 1872

Family PRODINOCERATIDAE Flerov, 1952

Genus PROBATHYOPSIS Simpson, 1929

Probathyopsis sp., cf. P. harrisorum (Patterson, 

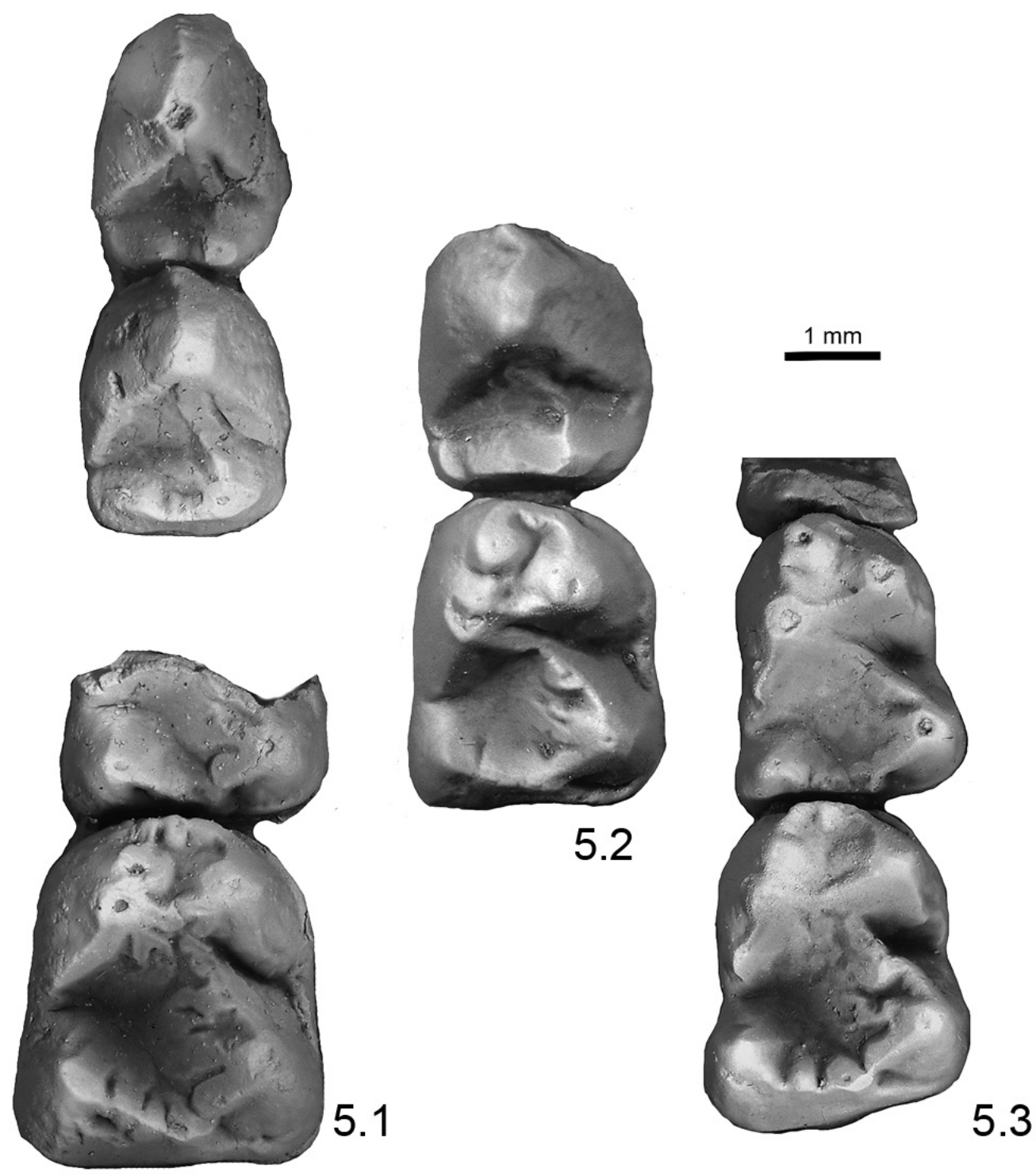

FIGURE 5. Primates. Comparative occlusal view of Plesiadapis dubius from Buckman Hollow. 5.1, USNM 16696 (holotype of $P$. "rubeyi"), 5.2, UCMP 173400. 5.3, USNM 20787 (holotype of P.? "pearcei”).

1939)

Figure 6.1-3

Newly referred material. UCMP 173492, partial right upper premolar or molar (Figure 6.1) from UCMP locality V96278.

Descriptions and remarks. The single specimen referred here to Probathyopsis sp., cf. P. harrisorum is part of the anterior half of an upper premolar or molar crown with a large portion of the labiolingually compressed lingual root still preserved. The tooth position of neither UCMP 173492 nor the previously referred USNM 21283 and 21284 (Figure 6.2-3) can be assigned with confidence, as P4 and
M1 are typically similar in size and morphology among dinoceratans. These can be readily distinguished from the teeth of other mammals from the Buckman Hollow local fauna based on large size, wrinkled enamel, and robust paracingulum (Thewissen and Gingerich, 1987). Specimens of Probathyopsis were previously recognized from Buckman Hollow by Gazin (1956), Dorr and Gingerich (1980), and Thewissen and Gingerich (1987). Thewissen and Gingerich (1987) questionably assigning UM specimens to $P$. harrisorum, observing that $P$. harrisorum and the stratigraphically older $P$. praecursor overlap in size and are most readily distinguished by anterior premolar 


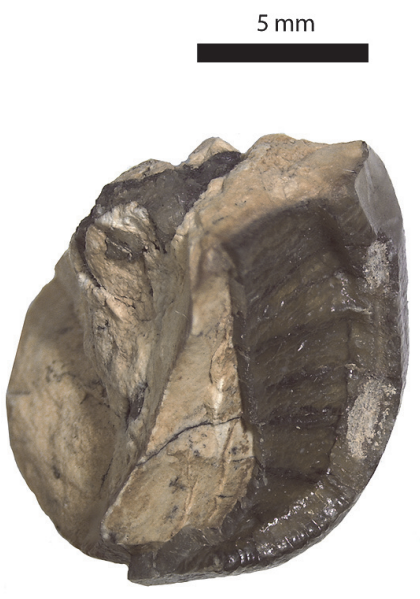

6.1

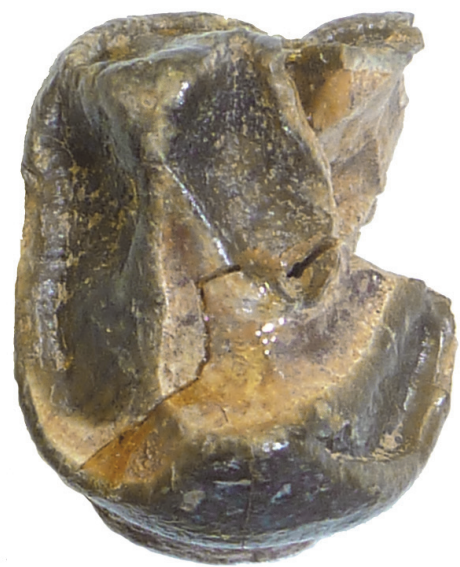

6.2

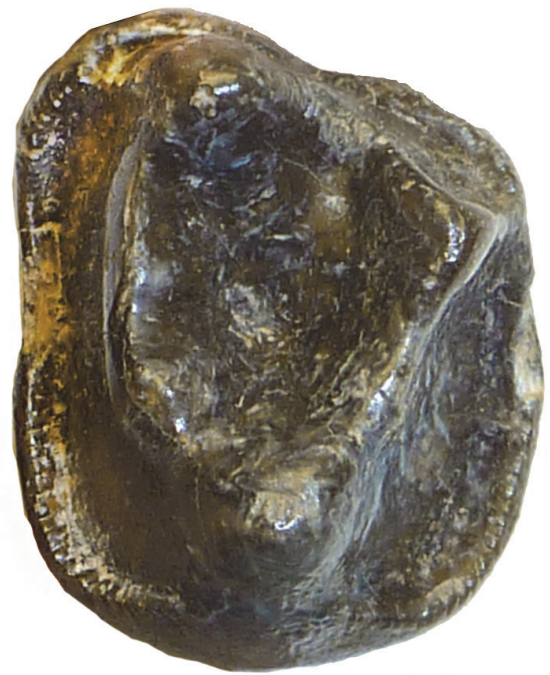

6.3

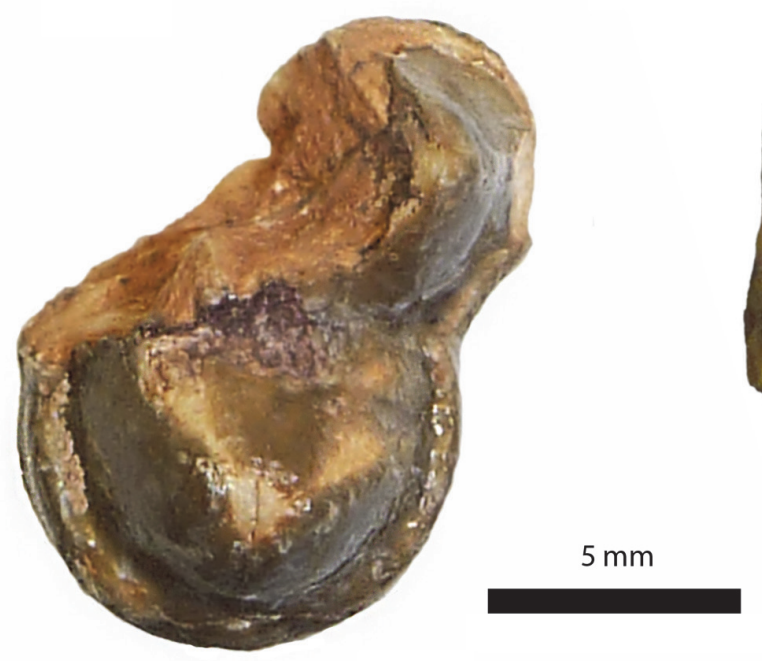

6.4

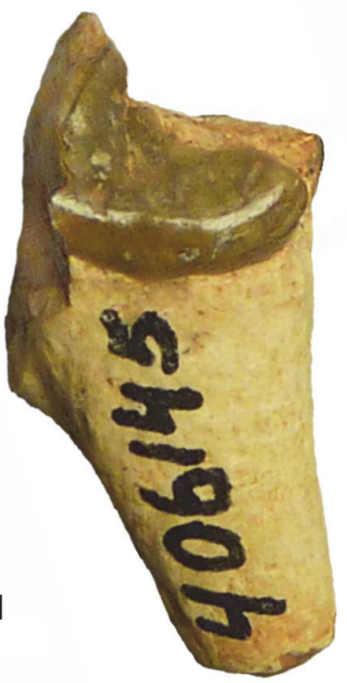

6.5

FIGURE 6. Dinocerata and Mesonychia. 6.1, Probathyopsis sp., cf. P. harrisorum, UCMP 173492, partial Px or M1. 6.2, Probathyopsis sp., cf. P. harrisorum, USNM 21284, Px (previously illustrated in Gazin, 1956, pl. 1, fig. 3). 6.3, Probathyopsis sp., cf. P. harrisorum, USNM 21283, Px or M1 (previously illustrated in Gazin, 1956, pl. 1, fig. 2). 6.4, Dissacus sp., cf. D. praenuntius, USNM 11699, partial left M2. 6.5, Dissacus sp., cf. D. praenuntius, USNM 406145, right $\mathrm{p} 2$ or $\mathrm{p} 3$ talonid.

characters and features of the astragalus. Based on its similarities to the homologous portions of the previously described USNM 21283, we follow Thewissen and Gingerich (1987) and questionably refer this specimen to $P$. harrisorum.

Order MESONYCHIA Matthew, 1937

Family MESONYCHIDAE Cope, 1881 Genus DISSACUS Cope, 1881

Dissacus sp., cf. D. praenuntius Matthew, 1915a Figure 6.4-5
Referred material. USNM 16699, partial left M2 (Figure 6.4); USNM 406145, right premolar talonid (Figure 6.5).

Descriptions and remarks. Two partial teeth are assigned here to Dissacus. As noted by O'Leary and Rose (1995), species within the genus are principally distinguished by differences in size and features of the lower dentition. Based on a comparison of USNM 16691 with the comparable parts of Clarkforkian specimens of $D$. praenuntius (YPM PU 13295 and 22314), the upper molar is similar in size and morphology to the second upper molar of $D$. praenuntius, a species known from the latest 
Tiffanian and latest Clarkforkian of the Bighorn Basin, differing only from these in having a continuous, rather than discontinuous, lingual cingulum. USNM 16691 is clearly larger than the Torrejonian to Tiffanian $D$. navajovicus and early Eocene $D$. willwoodensis (O'Leary and Rose, 1995). Gazin (1942) initially assigned USNM 16699 and an unvouchered second tooth fragment to "creodont, gen. and sp. undet." and later to Dissacus sp. (Gazin, 1956), suggesting that they were smaller than $D$. praenuntius and similar in size to Torrejonian $D$. navajovius. USNM 406145 is the only other specimen referable to a mesonychid in the USNM Buckman Hollow collections and is inferred to be the premolar fragment noted by Gazin (1956). Based on size, it is likely a p3 fragment; $p 2$ has an even shorter talonid in $D$. praenuntius and $\mathrm{p} 4$ of that species typically has a larger and more labially positioned talonid cusp. Our comparisons indicate these teeth belong to a larger species of Dissacus, and we tentatively assign them to $D$. praenuntius, extending the geographic range of the species southwards from northwestern Wyoming.

Order CONDYLARTHRA Cope, 1881

Family PHENACODONTIDAE Cope, 1881

Genus PHENACODUS Cope, 1873b

Phenacodus intermedius Granger, 1915

Figure 7.1

Newly referred material. UCMP 170704, right P3 and $\mathrm{P} 4$, and left M1 (parastylar lobe and paracone missing), and associated incomplete left and right dentaries with left $\mathrm{p} 3-4$ and right $\mathrm{m} 1-3$ (Figure 7.1); UCMP 173516, left P3; UCMP 173403, left upper molar fragment; UCMP 173402, right lower canine. UCMP 170702-170704 are from UCMP locality V96274, UCMP 173516 from UCMP locality V96291.

Description and remarks. Phenacodontid condylarths are exceedingly common members of most late Paleocene faunas, comprising nearly half of all the specimens recovered from Clarkforkian localities in the Bighorn Basin (Rose, 1981; Thewissen, 1990). The specimens referred here fall within the range of both metric and morphological variation of homologous teeth of Phenacodus intermedius reported by Thewissen (1990), including P4 being nearly as wide as it is long (i.e., subquadrate in occlusal outline). Measurements are given in Tables 1 and 2 and comparative statistics in Tables 3 and 4.

Gazin (1956) initially identified two specimens (USNM 20644 and 21287) from the Buckman Hollow local fauna as Phenacodus primaevus Cope, $1873 b$, and West (1976) repeated this identification in his list of phenacodontids from Buckman Hollow. Dorr and Gingerich (1980) later re-assigned these specimens to $P$. grangeri Simpson, 1935 and further reported on additional specimens of this species from the assemblage. Subsequently, Thewissen (1990) discussed the ambiguity surrounding $P$. primaevus and restricted the nomen to the holotype (AMNH 4408), an isolated $\mathrm{m} 3$ from the late Wasatchian of Wyoming. $P$. grangeri, which is close in size and morphology to $P$. intermedius, is known from the middle to late Tiffanian (Ti3-Ti6) and can be differentiated from P. intermedius in having a more subrectangular P4 (Thewissen, 1990). The specimens previously referred to $P$. primaevus and $P$. grangeri from the Buckman Hollow local fauna specimens are now best placed in P. intermedius (Thewissen, 1990), but we note that USNM specimens referred to this species and listed as being from Buckman Hollow by Thewissen under "USNM field number 29-61" are instead from the Chappo fauna.

$$
\text { Phenacodus vortmani (Cope, 1880) }
$$

Newly referred material. UCMP 173495 , incomplete right dentary with $\mathrm{m} 1$ from UCMP locality V96278.

Description and remarks. Based on a small sample of specimens from the Buckman Hollow local fauna, including a partial skull (USNM 16691), Gazin (1942, 1956) identified and described Phenacodus almiensis. Subsequent authors (e.g., Rose, 1981; Dorr and Gingerich, 1980) assigned additional material from the local fauna to this taxon. West (1976) synonymized P. almiensis with $P$. vortmani (Cope, 1880) based on similarity in size to Tiffanian $P$. vortmani from the Bighorn Basin and having interpreted the Buckman Hollow fauna as Tiffanian in age. He noted that only the holotype of $P$. almiensis (USNM 16691) showed the morphologically advanced presence of a hypocone on P4 and regarded it as a local variant. It is unclear whether West (1976) included specimens from the Tiffanian Chappo locality (originally identified in the USNM as "new Buckman Hollow faunal locality" and Gazin's field number 29-61) in his characterization of $P$. vortmani from Buckman Hollow. No list of attributed specimens was given, but based on his plots of molar dimensions (West, 1976, figure 23), West did examine at least six M1s, four M2s, five $\mathrm{m} 1 \mathrm{~s}$, and three $\mathrm{m} 2 \mathrm{~s}$. We did not find that many specimens from Buckman Hollow at the USNM with measurable teeth at those tooth positions that could be attributed to P.vortmani (see Tables 1, 2 

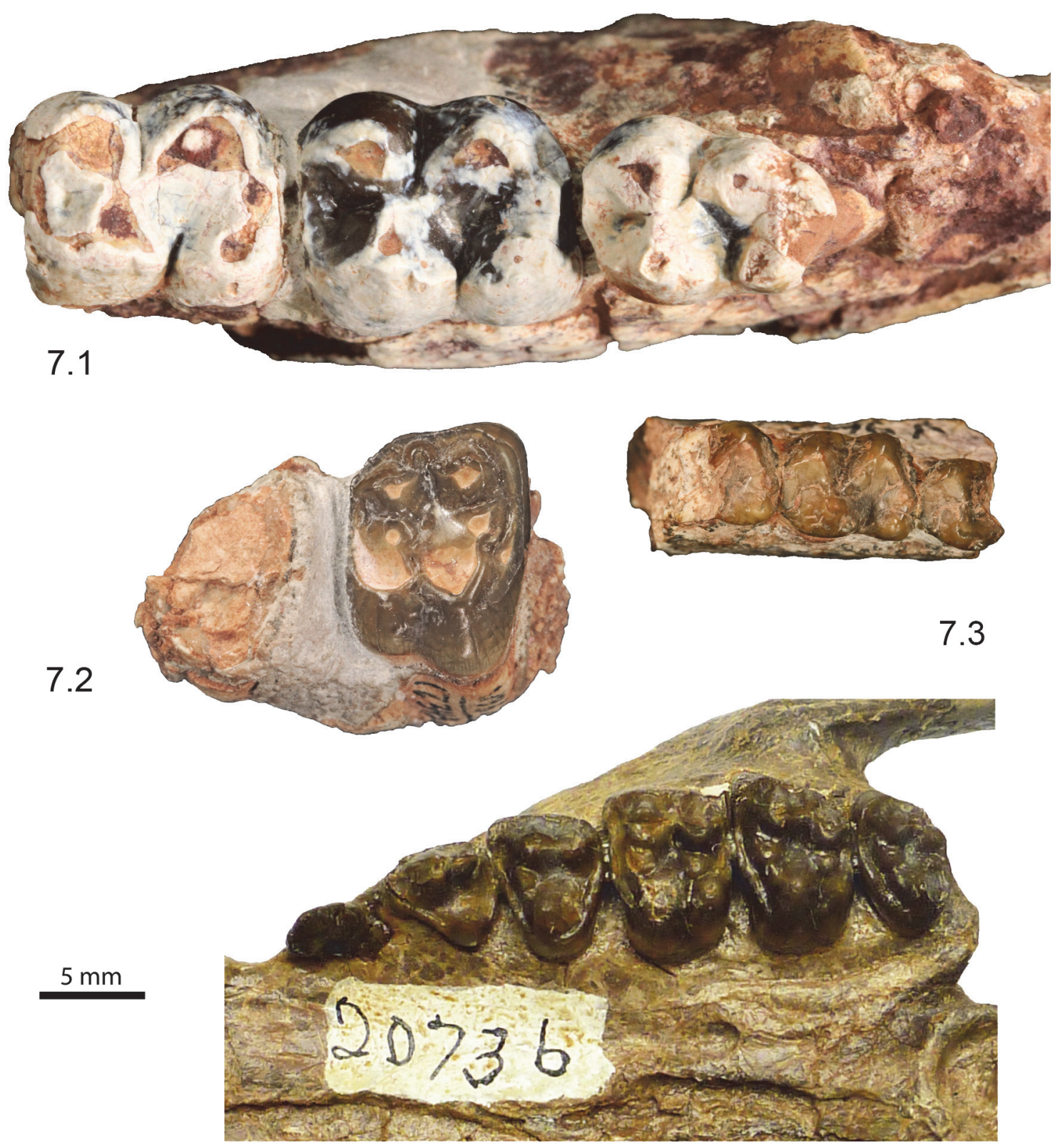

\section{4}

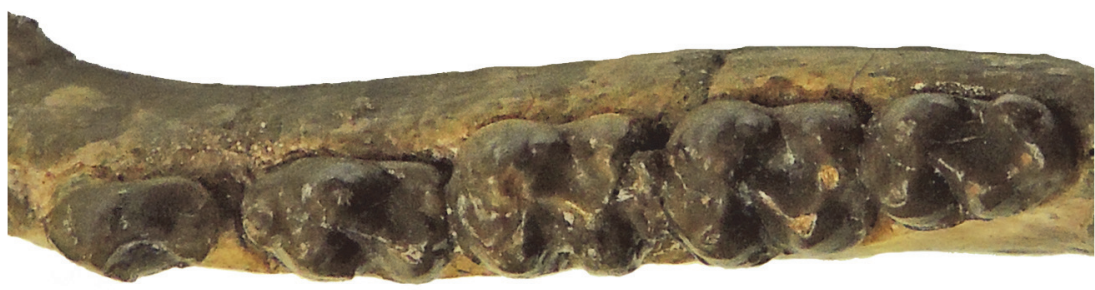

FIGURE 7. Phenacodontid condylarths. 7.1, Phenacodus intermedius, UCMP 170704, right dentary with m1-3. 7.2, Ectocion cf. E. major, UCMP 173496, right maxilla with M2. 7.3, Ectocion osbornianus, UCMP 173401, right dentary with partial m1, m2, partial m3. 7.4, E. osbornianus, USNM 20736, left maxilla with P2-M3 and dentary with p3-m3. 
TABLE 1. Measurements of the upper dentition of phenacodontids from the middle Clarkforkian (Cf2) Buckman Hollow local fauna, southwestern Wyoming.

\begin{tabular}{|c|c|c|c|c|c|c|c|c|c|c|c|}
\hline Taxon & Specimen Number & P3L & P3W & P4L & P4W & M1L & M1W & M2L & M2W & M3L & M3W \\
\hline \multirow{11}{*}{$\begin{array}{l}\text { Phenacodus } \\
\text { vortmani }\end{array}$} & USNM 16693 & 7.9 & 7.3 & - & - & - & - & - & - & - & - \\
\hline & UCMP 173516 & - & 8.6 & - & - & - & - & - & - & - & - \\
\hline & $\begin{array}{l}\text { USNM } 21286 \text { (R, } \\
\text { except M3) }\end{array}$ & - & 8.6 & 8.0 & 9.0 & 9.0 & 10.1 & 8.7 & 12.1 & 8.7 & 10.0 \\
\hline & USNM 16691 (L) & 8.4 & 7.5 & 8.5 & 8.5 & 9.0 & 8.3 & 9.0 & 11.5 & - & - \\
\hline & USNM 16691 (R) & 8.3 & 7.8 & 8.1 & 8.5 & 9.1 & 9.9 & - & - & 8.0 & 10.2 \\
\hline & USNM 406166 & - & - & 7.8 & 9.5 & 9.4 & 12.0 & 9.3 & 11.6 & 7.8 & 9.6 \\
\hline & USNM 20651 & - & - & - & - & 8.8 & - & 8.7 & 11.5 & - & - \\
\hline & USNM 16694 & - & - & - & - & - & - & - & - & 7.4 & 10.4 \\
\hline & USNM 20639 & - & - & - & - & - & - & - & - & 8.2 & 10.6 \\
\hline & USNM 406160 & - & - & - & - & - & - & - & - & 7.3 & 9.1 \\
\hline & USNM 406161 & - & - & - & - & - & - & - & - & 8.8 & 12.5 \\
\hline \multirow{4}{*}{$\begin{array}{l}\text { Phenacodus } \\
\text { intermedius }\end{array}$} & USNM 406156 & 9.6 & 8.3 & - & - & - & - & - & - & - & - \\
\hline & UCMP 170704 & 10.2 & 9.3 & 9.8 & 11.3 & - & - & - & - & - & - \\
\hline & USNM 409474 & - & - & 11.0 & 11.8 & - & - & - & - & - & - \\
\hline & USNM 20649 & - & - & 9.9 & 10.9 & - & - & 11.0 & 14.0 & - & - \\
\hline $\begin{array}{l}\text { Ectocion sp., cf. E. } \\
\text { major }\end{array}$ & UCMP 173496 & - & - & - & - & - & - & 10.3 & 12.2 & - & - \\
\hline \multirow{4}{*}{$\begin{array}{l}\text { Ectocion } \\
\text { osbornianus }\end{array}$} & USNM 406151 & - & 5.7 & - & - & - & - & - & - & - & - \\
\hline & USNM 20736 (L) & 5.8 & 5.5 & 6.0 & 7.6 & 6.1 & 8.5 & 6.1 & 8.9 & 4.9 & 7.4 \\
\hline & USNM 20736 (R) & 5.9 & 5.4 & - & 6.2 & 7.2 & 8.5 & - & 8.4 & 4.9 & 7.2 \\
\hline & USNM 406154 & - & - & - & - & - & - & - & - & 6.5 & 8.8 \\
\hline
\end{tabular}

for measurements of specimens of $P$. vortmani found in the USNM collections).

Thewissen (1990) also considered $P$. "almiensis" a junior synonym of $P$. vortmani, but noted several differences between the sample of $P$. vortmani from Buckman Hollow and samples of the species from other Clarkforkian assemblages, including a taller mesostyle on the upper molars from Buckman Hollow. The synonymy proposed by Thewissen (1990) is followed here, but we note that future work to determine whether regional variants in size or morphology exist in this abundant taxon might be fruitful.

Genus ECTOCION Cope, 1882a

Ectocion sp., cf. E. major (Patterson and West, 1973)

Figure 7.2

Referred material. UCMP 173496, incomplete right maxilla with $\mathrm{M} 2(\mathrm{~L}=10.3 \mathrm{~mm}, \mathrm{~W}=12.2 \mathrm{~mm})$ from UCMP locality V96278 (Figure 7.2).
Description. The crown of the referred M2 is subrectangular in occlusal outline and the principal cusps are swollen, especially near their bases. The smoothly rounded parastylar lobe is expanded labially and slightly anteriorly. The paracone is approximately equal in size to the metacone but the base of the paracone extends further labially; the centrocrista is deflected labially to the base of a bulbous mesostyle. A small swelling lingual to the mesostyle is developed on the ectocingulum. Both the paraconule and metaconule are inflated; however, the paraconule is somewhat larger than the metaconule and more labially positioned. The base of the protocone is more massive than that of either the paracone or metacone. The hypocone is inflated and supported on the expanded postcingulum. The heavily worn anterior cingulum is low, except as it wraps around the anterolabial corner of the crown, and forms a narrow shelf along much of the anterior margin of the crown; the base of a small cuspule is present on the anterior cingulum, just anterior to the protocone. 
TABLE 2. Measurements of the lower dentition of phenacodontids from the middle Clarkforkian (Cf2) Buckman Hollow local fauna, southwestern Wyoming.

\begin{tabular}{|c|c|c|c|c|c|c|c|c|c|c|c|}
\hline Taxon & Specimen Number & p3L & p3W & p4L & p4L & m1L & $\mathrm{m} 1 \mathrm{~W}$ & m2L & $\mathrm{m} 2 \mathrm{~W}$ & m3L & $\mathrm{m} 3 \mathrm{~W}$ \\
\hline \multirow{11}{*}{$\begin{array}{l}\text { Phenacodus } \\
\text { vortmani }\end{array}$} & USNM 406161 & 8.4 & 4.9 & - & - & - & - & - & - & - & - \\
\hline & USNM 20642 & - & - & 9.2 & 5.9 & - & - & - & - & - & - \\
\hline & USNM 20653 & - & - & 9.7 & 7.3 & - & - & - & - & - & - \\
\hline & USNM 20643 & - & - & 9.6 & 6.4 & 9.0 & 7.2 & - & - & - & - \\
\hline & UCMP 173495 & - & - & - & - & 9.0 & 7.3 & - & - & - & - \\
\hline & USNM 20654 & - & - & - & - & 9.0 & 7.9 & 9.9 & 8.2 & - & - \\
\hline & USNM 20638 & - & - & - & - & 9.4 & 8.7 & 9.5 & 7.8 & 10.0 & 6.7 \\
\hline & USNM 20650 & - & - & - & - & 9.5 & 7.9 & 9.8 & 8.0 & - & 7.4 \\
\hline & USNM 21286 & - & - & - & - & - & - & 9.3 & - & 9.4 & - \\
\hline & USNM 20637 & - & - & - & - & - & - & - & - & 10.8 & 7.7 \\
\hline & USNM 409469 & - & - & - & - & - & - & - & - & 10.4 & 6.9 \\
\hline \multirow{3}{*}{$\begin{array}{l}\text { Phenacodus } \\
\text { intermedius }\end{array}$} & USNM 21287 & 12.0 & 7.7 & 12.6 & 10.0 & 12.5 & 11.4 & 13.2 & 12.7 & - & - \\
\hline & USNM 20644 & - & - & 11.8 & 7.9 & 12.1 & 9.8 & - & - & - & - \\
\hline & UCMP 170704 & - & - & - & - & 12.3 & 10.7 & 12.1 & 11.3 & 11.8 & 8.8 \\
\hline \multirow{10}{*}{$\begin{array}{l}\text { Ectocion } \\
\text { osbornianus }\end{array}$} & USNM 20736 (R) & 5.6 & 3.5 & 6.6 & 4.2 & 6.6 & 5.2 & 6.4 & 5.4 & 6.3 & 4.5 \\
\hline & USNM 20736 (L) & 5.5 & 3.4 & 6.8 & 4.2 & 7.1 & 5.2 & 6.8 & 5.4 & 7.1 & 4.5 \\
\hline & USNM 16695 & - & - & 6.1 & 4.6 & - & - & - & - & - & - \\
\hline & USNM 20645 & - & - & 7.4 & 5.1 & 6.8 & 5.8 & 7.0 & 6.7 & - & - \\
\hline & USNM 20646 & - & - & - & - & 7.4 & 5.4 & - & - & - & - \\
\hline & UCMP 173493 & - & - & - & - & - & - & 6.7 & 5.9 & - & - \\
\hline & USNM 20648 & - & - & - & - & 6.7 & 5.3 & 6.6 & 5.7 & - & - \\
\hline & UCMP 173401 & - & - & - & - & - & 4.8 & 6.9 & 5.1 & - & 4.4 \\
\hline & USNM 20640 & - & - & - & - & 7.0 & 5.3 & 7.0 & 5.7 & 8.2 & 5.3 \\
\hline & USNM 406146 & - & - & - & - & - & - & - & - & 8.1 & 4.7 \\
\hline
\end{tabular}

Remarks. Ectocion major was originally described from northwestern Colorado by Patterson and West (1973) as Prosthecion major, but only fragments of upper molars were described. Thewissen (1990) attributed additional specimens to this species and referred it to Ectocion. UCMP 173496 closely resembles the M2 of Clarkforkian Ectocion major and differs only in being slightly larger than the sample assigned to this species by Thewissen (1990). It falls within the size range of Phenacodus vortmani, but morphologically differs from that species in that the mesostyle is larger and the margins of the crown are considerably less swollen, imparting a more rectangular outline. This specimen represents the first report of a larger species of Ectocion from the Buckman Hollow fauna. As noted by Thewissen (1990), E. major is a rare taxon being known from few $(n=16)$ specimens from the Bighorn and Piceance Basins.

\section{Ectocion osbornianus (Cope, 1882b)}

Figure 7.3-4

Newly referred material. UCMP 173401, incomplete right dentary with $\mathrm{m} 1$ talonid, $\mathrm{m} 2$, and $\mathrm{m} 3$ trigonid $(\mathrm{m} 2, \mathrm{~L}=6.9 \mathrm{~mm}, \mathrm{TrW}=5.9 \mathrm{~mm}, \mathrm{TaW}=5.7$ $\mathrm{mm} ; \mathrm{m3}$, TrW $=4.5 \mathrm{~mm}$ ) from UCMP locality V96274 (Figure 7.3); UCMP 173493, right $\mathrm{m} 2(\mathrm{~L}=$ $6.7 \mathrm{~mm}, \mathrm{TrW}=5.9 \mathrm{~mm}$., TaW $=5.7 \mathrm{~mm}$ ) from UCMP locality V96278.

Description and remarks. Two species of Ectocion have previously been recognized from the Buckman Hollow local fauna: $E$. osbornianus (Cope, 1882b) and E. mediotuber Thewissen, 1990 (see Gazin, 1956; Dorr and Gingerich, 1980; Thewissen, 1990). Though E. osbornianus is known from multiple referred specimens (Dorr and Gingerich, 1980; Thewissen, 1990; Tables 1, 2), the occurrence of E. mediotuber at Buckman Hol- 
TABLE 3. Descriptive summary statistics of the upper dentition of phenacodontids from Buckman Hollow and other Clarkforkian and other earliest Wasatchian assemblages from the Western Interior of North America. Comparative data from Thewissen (1990), Burger (2012), and Rose et al. (2012).

\begin{tabular}{|c|c|c|c|c|c|c|c|c|c|c|c|c|}
\hline Taxon & $\begin{array}{l}\text { Sedimentary } \\
\text { Basin }\end{array}$ & & P3L & P3W & P4L & P4W & M1L & M1W & M2L & M2W & M3L & M3W \\
\hline \multirow[t]{12}{*}{$\begin{array}{l}\text { Phenacodus } \\
\text { vortmani }\end{array}$} & $\begin{array}{c}\text { Buckman } \\
\text { Hollow }\end{array}$ & $\mathrm{n}$ & 3 & 5 & 4 & 4 & 5 & 4 & 4 & 4 & 7 & 7 \\
\hline & & Mean & 8.2 & 8.0 & 8.1 & 8.9 & 9.1 & 10.1 & 8.9 & 11.7 & 8.0 & 10.4 \\
\hline & & SD & 0.2 & 0.6 & 0.3 & 0.5 & 0.2 & 1.6 & 0.3 & 0.3 & 0.6 & 1.1 \\
\hline & & SE & 0.1 & 0.3 & 0.1 & 0.2 & 0.1 & 0.8 & 0.2 & 0.1 & 0.2 & 0.4 \\
\hline & & Minimum & 7.9 & 7.3 & 7.8 & 8.5 & 8.8 & 8.3 & 8.7 & 11.5 & 7.3 & 9.1 \\
\hline & & Maximum & 8.4 & 8.6 & 8.5 & 9.5 & 9.4 & 12.0 & 9.3 & 12.1 & 8.8 & 12.5 \\
\hline & $\begin{array}{l}\text { Bighorn Basin } \\
\text { Cf } 2\end{array}$ & $\mathrm{n}$ & & & & 1 & 2 & 2 & 2 & 2 & 4 & 4 \\
\hline & & Mean & & & & 9.6 & 9.4 & 11.2 & 9.8 & 10.5 & 9.5 & 8.9 \\
\hline & & SD & & & & & & 0.6 & 0.4 & 0.4 & 0.1 & 0.7 \\
\hline & & SE & & & & & & 0.4 & 0.3 & 0.3 & 0.1 & 0.4 \\
\hline & & Minimum & & & & & 9.0 & 10.9 & 9.5 & 10.4 & 8.6 & 7.7 \\
\hline & & Maximum & & & & & 9.8 & 11.4 & 10.0 & 10.6 & 10.3 & 9.6 \\
\hline \multirow[t]{18}{*}{$\begin{array}{l}\text { Phenacodus } \\
\text { intermedius }\end{array}$} & $\begin{array}{c}\text { Buckman } \\
\text { Hollow }\end{array}$ & $\mathrm{n}$ & 2 & 2 & 3 & 3 & & & 1 & 1 & & \\
\hline & & Mean & 9.9 & 8.8 & 10.2 & 11.3 & & & 11.0 & 14.0 & & \\
\hline & & SD & 0.5 & 0.7 & 0.7 & 0.5 & & & & & & \\
\hline & & SE & 0.3 & 0.5 & 0.4 & 0.3 & & & & & & \\
\hline & & Minimum & 9.6 & 8.3 & 9.8 & 10.9 & & & & & & \\
\hline & & Maximum & 10.2 & 9.3 & 11.0 & 11.8 & & & & & & \\
\hline & $\begin{array}{l}\text { Bighorn Basin } \\
\quad \text { Cf2 }\end{array}$ & $\mathrm{n}$ & 12 & 14 & 21 & 24 & 20 & 22 & 29 & 29 & 38 & 40 \\
\hline & & Mean & 10.7 & 9.9 & 10.7 & 11.5 & 12.3 & 13.9 & 13.2 & 14.3 & 11.7 & 11.0 \\
\hline & & SD & 0.7 & 0.7 & 0.7 & 0.9 & 0.9 & 1.1 & 1.0 & 0.9 & 0.9 & 1.0 \\
\hline & & SE & 0.2 & 0.2 & 0.1 & 0.2 & 0.2 & 0.2 & 0.2 & 0.2 & 0.1 & 0.2 \\
\hline & & Minimum & 9.5 & 8.9 & 9.2 & 9.0 & 10.7 & 11.8 & 10.9 & 12.4 & 10.2 & 8.8 \\
\hline & & Maximum & 12.1 & 11.4 & 11.6 & 13.1 & 14.5 & 16.3 & 16.1 & 15.7 & 14.0 & 14.2 \\
\hline & $\begin{array}{l}\text { Bighorn Basin } \\
\text { WaO }\end{array}$ & $\mathrm{n}$ & 1 & 1 & 1 & 1 & & & & & & \\
\hline & & Mean & 8.0 & 8.4 & 8.3 & 9.2 & & & & & & \\
\hline & & SD & & & & & & & & & & \\
\hline & & SE & & & & & & & & & & \\
\hline & & Minimum & & & & & & & & & & \\
\hline & & Maximum & & & & & & & & & & \\
\hline \multirow[t]{3}{*}{$\begin{array}{l}\text { Ectocion sp., } \\
\text { cf. E. major }\end{array}$} & $\begin{array}{c}\text { Buckman } \\
\text { Hollow }\end{array}$ & $\mathrm{n}$ & & & & & & & 1 & 1 & & \\
\hline & & Mean & & & & & & & 10.3 & 12.2 & & \\
\hline & & SD & & & & & & & & & & \\
\hline
\end{tabular}


TABLE 3 (continued).

\begin{tabular}{|c|c|c|c|c|c|c|c|c|c|c|c|c|}
\hline Taxon & $\begin{array}{c}\text { Sedimentary } \\
\text { Basin }\end{array}$ & & P3L & P3W & P4L & P4W & M1L & M1W & M2L & M2W & M3L & M3W \\
\hline & & SE & & & & & & & & & & \\
\hline & & Minimum & & & & & & & & & & \\
\hline & & Maximum & & & & & & & & & & \\
\hline \multirow[t]{12}{*}{$\begin{array}{l}\text { Ectocion } \\
\text { osbornianus }\end{array}$} & $\begin{array}{l}\text { Buckman } \\
\text { Hollow }\end{array}$ & $\mathrm{n}$ & 2 & 3 & 1 & 2 & 2 & 2 & 1 & 2 & 3 & 3 \\
\hline & & Mean & 5.9 & 5.5 & 6.0 & 6.9 & 6.7 & 8.5 & 6.1 & 8.7 & 5.4 & 7.8 \\
\hline & & SD & 0.1 & 0.1 & & 1.0 & 0.8 & 0.0 & & 0.4 & 0.9 & 0.9 \\
\hline & & SE & 0.1 & 0.1 & & 0.7 & 0.5 & 0.0 & & 0.3 & 0.5 & 0.5 \\
\hline & & Minimum & 5.8 & 5.4 & & 6.2 & 6.1 & 8.5 & & 8.4 & 4.9 & 7.2 \\
\hline & & Maximum & 5.9 & 5.7 & & 7.6 & 7.2 & 8.5 & & 8.9 & 6.5 & 8.8 \\
\hline & Bighorn Basin & $\mathrm{n}$ & 45 & 46 & 53 & 54 & 85 & 88 & 96 & 108 & 63 & 66 \\
\hline & & Mean & 6.2 & 6.2 & 6.6 & 7.8 & 7.2 & 8.7 & 7.6 & 8.9 & 6.2 & 7.0 \\
\hline & & SD & 0.3 & 0.5 & 0.4 & 0.6 & 0.4 & 0.5 & 0.5 & 0.5 & 0.5 & 0.5 \\
\hline & & SE & 0.1 & 0.1 & 0.1 & 0.1 & 0.0 & 0.1 & 0.1 & 0.1 & 0.1 & 0.1 \\
\hline & & Minimum & 5.2 & 4.9 & 5.8 & 5.6 & 6.4 & 7.3 & 6.2 & 7.7 & 5.2 & 5.6 \\
\hline & & Maximum & 6.7 & 6.9 & 7.2 & 8.8 & 8.0 & 10.0 & 8.9 & 10.1 & 7.5 & 8.0 \\
\hline \multirow[t]{18}{*}{$\begin{array}{l}\text { Ectocion } \\
\text { parvus }\end{array}$} & $\begin{array}{c}\text { Bighorn Basin } \\
\text { Cf2 }\end{array}$ & $\mathrm{n}$ & 2 & 2 & 2 & 2 & 4 & 4 & 8 & 7 & 5 & 5 \\
\hline & & Mean & 5.2 & 5.1 & 5.6 & 6.6 & 5.7 & 7.4 & 6.3 & 7.3 & 5.2 & 6.1 \\
\hline & & SD & 0.3 & 0.2 & 0.2 & 0.4 & 0.1 & 0.1 & 0.4 & 0.5 & 0.7 & 0.5 \\
\hline & & SE & 0.2 & 0.2 & 0.1 & 0.3 & 0.0 & 0.0 & 0.1 & 0.2 & 0.3 & 0.2 \\
\hline & & Minimum & 5.0 & 5.0 & 5.5 & 6.3 & 5.6 & 7.3 & 5.7 & 6.7 & 4.4 & 5.5 \\
\hline & & Maximum & 5.4 & 5.3 & 5.7 & 6.8 & 6.2 & 7.4 & 7.0 & 7.8 & 5.8 & 6.6 \\
\hline & Bighorn Basin & $\mathrm{n}$ & 2 & 2 & 3 & 4 & 7 & 7 & 15 & 15 & 9 & 9 \\
\hline & & Mean & 4.7 & 4.7 & 5.4 & 6.5 & 5.6 & 6.8 & 5.6 & 7.2 & 4.9 & 6.2 \\
\hline & & SD & 0.3 & 0.6 & 0.2 & 0.4 & 0.3 & 0.6 & 0.3 & 0.5 & 0.8 & 0.8 \\
\hline & & SE & 0.2 & 0.4 & 0.1 & 0.2 & 0.1 & 0.2 & 0.1 & 0.1 & 0.3 & 0.3 \\
\hline & & Minimum & 4.6 & 4.3 & 5.2 & 6.0 & 5.3 & 6.1 & 4.9 & 6.4 & 4.1 & 4.9 \\
\hline & & Maximum & 4.9 & 5.1 & 5.5 & 6.9 & 6.0 & 7.5 & 6.2 & 7.9 & 6.6 & 7.2 \\
\hline & $\begin{array}{l}\text { Piceance } \\
\text { Creek }\end{array}$ & $\mathrm{n}$ & 1 & 1 & 1 & 1 & 1 & 1 & 1 & 1 & 4 & 4 \\
\hline & & Mean & 5.4 & 4.9 & 5.4 & 6.1 & 5.8 & 7.5 & 5.6 & 7.5 & 4.9 & 7.0 \\
\hline & & SD & & & & & & & & & 0.1 & 0.1 \\
\hline & & SE & & & & & & & & & 0.1 & 0.1 \\
\hline & & Minimum & & & & & & & & & 4.9 & 6.8 \\
\hline & & Maximum & & & & & & & & & 5.2 & 7.1 \\
\hline
\end{tabular}


TABLE 4. Descriptive summary statistics of the lower dentition of phenacodontids from Buckman Hollow and other Clarkforkian and other earliest Wasatchian assemblages from the Western Interior of North America. Comparative data from Thewissen (1990), Burger (2012), and Rose et al. (2012).

\begin{tabular}{|c|c|c|c|c|c|c|c|c|c|c|c|c|}
\hline Taxon & Assemblage & & p3L & p3W & p4L & $\mathrm{p} 4 \mathrm{~W}$ & m1L & m1W & m2L & $\mathrm{m} 2 \mathrm{~W}$ & m3L & $\mathrm{m} 3 \mathrm{~W}$ \\
\hline \multirow{12}{*}{$\begin{array}{l}\text { Phenacodus } \\
\text { vortmani }\end{array}$} & Buckman Hollow & $\mathrm{n}$ & 1 & 1 & 3 & 3 & 5 & 5 & 4 & 3 & 4 & 4 \\
\hline & & Mean & 8.4 & 4.9 & 9.5 & 6.5 & 9.2 & 7.8 & 9.6 & 8.0 & 10.2 & 7.2 \\
\hline & & SD & & & 0.3 & 0.7 & 0.2 & 0.6 & 0.3 & 0.2 & 0.6 & 0.5 \\
\hline & & SE & & & 0.2 & 0.4 & 0.1 & 0.3 & 0.1 & 0.1 & 0.3 & 0.2 \\
\hline & & Minimum & & & 9.2 & 5.9 & 9.0 & 7.2 & 9.3 & 7.8 & 9.4 & 6.7 \\
\hline & & Maximum & & & 9.7 & 7.3 & 9.5 & 8.7 & 9.9 & 8.2 & 10.8 & 7.7 \\
\hline & $\begin{array}{c}\text { Bighorn Basin } \\
\text { Cf2 }\end{array}$ & $\mathrm{n}$ & 3 & 3 & 6 & 6 & 4 & 3 & 5 & 7 & 7 & 7 \\
\hline & & Mean & 8.5 & 5.6 & 9.5 & 6.5 & 9.6 & 7.7 & 9.7 & 8.1 & 9.8 & 6.9 \\
\hline & & SD & 0.4 & 0.2 & 0.3 & 0.5 & 0.5 & 0.4 & 0.2 & 0.3 & 0.8 & 0.6 \\
\hline & & SE & 0.2 & 0.1 & 0.1 & 0.2 & 0.2 & 0.2 & 0.1 & 0.1 & 0.3 & 0.2 \\
\hline & & Minimum & 8.1 & 5.4 & 9.1 & 5.7 & 9.0 & 7.2 & 9.5 & 7.7 & 8.5 & 6.3 \\
\hline & & Maximum & 8.8 & 5.7 & 9.8 & 7.1 & 10.0 & 7.9 & 10.0 & 8.4 & 11.0 & 7.6 \\
\hline \multirow{18}{*}{$\begin{array}{l}\text { Phenacodus } \\
\text { intermedius }\end{array}$} & Buckman Hollow & $\mathrm{n}$ & 1 & 1 & 2 & 2 & 3 & 3 & 2 & 2 & 1 & 1 \\
\hline & & Mean & 12.0 & 7.7 & 12.2 & 9.0 & 12.3 & 10.6 & 12.7 & 12.0 & 11.8 & 8.8 \\
\hline & & SD & & & 0.6 & 1.5 & 0.2 & 0.8 & 0.78 & 1.0 & & \\
\hline & & SE & & & 0.4 & 1.1 & 0.1 & 0.5 & 0.56 & 0.7 & & \\
\hline & & Minimum & & & 11.8 & 7.9 & 12.1 & 10.0 & 12.1 & 11.3 & & \\
\hline & & Maximum & & & 12.6 & 10.0 & 12.5 & 11.4 & 13.2 & 12.7 & & \\
\hline & $\begin{array}{c}\text { Bighorn Basin } \\
\text { Cf2 }\end{array}$ & $\mathrm{n}$ & 18 & 22 & 33 & 34 & 44 & 40 & 44 & 47 & 41 & 41 \\
\hline & & Mean & 10.9 & 6.9 & 11.9 & 8.6 & 12.4 & 10.3 & 12.8 & 11.3 & 13.1 & 9.8 \\
\hline & & SD & 0.6 & 0.6 & 0.8 & 0.7 & 0.7 & 0.6 & 0.7 & 0.8 & 0.9 & 0.6 \\
\hline & & SE & 0.1 & 0.1 & 0.1 & 0.1 & 0.1 & 0.1 & 0.1 & 0.1 & 0.1 & 0.1 \\
\hline & & Minimum & 10.2 & 5.4 & 10.2 & 7.5 & 11.1 & 9.3 & 11.2 & 9.6 & 11.4 & 8.4 \\
\hline & & Maximum & 12.1 & 8.1 & 13.5 & 10.1 & 14.0 & 11.6 & 14.3 & 12.9 & 15.2 & 10.7 \\
\hline & $\begin{array}{l}\text { Bighorn Basin } \\
\quad(\mathrm{WaO})\end{array}$ & $\mathrm{n}$ & 2 & 2 & 2 & 2 & 2 & 1 & 1 & 1 & 2 & 2 \\
\hline & & Mean & 9.0 & 5.6 & 9.7 & 6.4 & 10.6 & 8.6 & 10.4 & 9.4 & 10.4 & 8.0 \\
\hline & & SD & 0.2 & 0.4 & 0.9 & 0.4 & 0.1 & & & & 0.7 & 0.6 \\
\hline & & SE & 0.2 & 0.3 & 0.6 & 0.3 & 0.1 & & & & 0.5 & 0.5 \\
\hline & & Minimum & 8.8 & 5.3 & 9.1 & 6.2 & 10.5 & & & & 9.9 & 7.5 \\
\hline & & Maximum & 9.1 & 5.8 & 10.3 & 6.7 & 10.7 & & & & 10.9 & 8.4 \\
\hline
\end{tabular}


TABLE 4 (continued).

\begin{tabular}{|c|c|c|c|c|c|c|c|c|c|c|c|c|}
\hline Taxon & Assemblage & & p3L & p3W & p4L & p4W & m1L & $\mathrm{m} 1 \mathrm{~W}$ & m2L & $\mathrm{m} 2 \mathrm{~W}$ & m3L & $\mathrm{m} 3 \mathrm{~W}$ \\
\hline \multirow{12}{*}{$\begin{array}{l}\text { Ectocion } \\
\text { osbornianus }\end{array}$} & Buckman Hollow & $\mathrm{n}$ & 2 & 2 & 4 & 4 & 6 & 7 & 7 & 7 & 4 & 5 \\
\hline & & Mean & 5.6 & 3.4 & 6.7 & 4.5 & 6.9 & 5.3 & 6.8 & 5.7 & 7.4 & 4.7 \\
\hline & & SD & 0.1 & 0.1 & 0.5 & 0.4 & 0.3 & 0.3 & 0.2 & 0.5 & 0.9 & 0.4 \\
\hline & & SE & 0.1 & 0.1 & 0.3 & 0.2 & 0.1 & 0.1 & 0.1 & 0.2 & 0.5 & 0.2 \\
\hline & & Minimum & 5.5 & 3.4 & 6.1 & 4.2 & 6.6 & 4.8 & 6.4 & 5.4 & 6.3 & 4.4 \\
\hline & & Maximum & 5.6 & 3.5 & 7.4 & 5.1 & 7.4 & 5.9 & 7.0 & 6.7 & 8.2 & 5.3 \\
\hline & Bighorn Basin & $\mathrm{n}$ & 49 & 52 & 98 & 103 & 173 & 181 & 178 & 187 & 91 & 105 \\
\hline & & Mean & 6.6 & 3.7 & 6.7 & 4.7 & 6.6 & 5.2 & 6.7 & 5.6 & 7.2 & 4.8 \\
\hline & & SD & 0.4 & 0.3 & 0.4 & 0.3 & 0.3 & 0.3 & 0.4 & 0.4 & 0.4 & 0.3 \\
\hline & & SE & 0.1 & 0.0 & 0.0 & 0.0 & 0.0 & 0.0 & 0.0 & 0.0 & 0.1 & 0.0 \\
\hline & & Minimum & 5.7 & 3.0 & 5.8 & 4.1 & 5.8 & 4.5 & 5.6 & 4.5 & 6.3 & 4.1 \\
\hline & & Maximum & 7.3 & 4.3 & 7.7 & 5.8 & 7.5 & 6.4 & 7.6 & 6.6 & 8.2 & 6.1 \\
\hline \multirow[t]{18}{*}{$\begin{array}{l}\text { Ectocion } \\
\text { parvus }\end{array}$} & $\begin{array}{c}\text { Bighorn Basin } \\
\text { Cf2 }\end{array}$ & $\mathrm{n}$ & 3 & 4 & 14 & 14 & 11 & 9 & 10 & 14 & 6 & 8 \\
\hline & & Mean & 5.8 & 3.1 & 5.8 & 3.8 & 5.5 & 4.4 & 5.5 & 4.6 & 5.9 & 3.8 \\
\hline & & SD & 0.3 & 0.2 & 0.3 & 0.2 & 0.2 & 0.3 & 0.4 & 0.3 & 0.4 & 0.3 \\
\hline & & SE & 0.2 & 0.1 & 0.1 & 0.1 & 0.1 & 0.1 & 0.1 & 0.1 & 0.2 & 0.1 \\
\hline & & Minimum & 5.5 & 2.8 & 5.1 & 3.4 & 5.2 & 3.8 & 4.6 & 4.2 & 5.1 & 3.4 \\
\hline & & Maximum & 6.0 & 3.2 & 6.3 & 4.2 & 5.9 & 4.8 & 5.9 & 5.2 & 6.2 & 4.3 \\
\hline & $\begin{array}{l}\text { Bighorn Basin } \\
\text { WaO }\end{array}$ & $\mathrm{n}$ & 8 & 8 & 15 & 15 & 19 & 18 & 26 & 27 & 19 & 18 \\
\hline & & Mean & 5.5 & 3.0 & 5.7 & 3.8 & 5.5 & 4.4 & 5.7 & 4.6 & 5.9 & 3.8 \\
\hline & & SD & 0.4 & 0.2 & 0.3 & 0.4 & 0.3 & 0.2 & 0.5 & 0.3 & 0.4 & 0.3 \\
\hline & & SE & 0.1 & 0.1 & 0.1 & 0.1 & 0.1 & 0.1 & 0.1 & 0.1 & 0.1 & 0.1 \\
\hline & & Minimum & 4.9 & 2.6 & 4.8 & 2.7 & 5.1 & 4.0 & 3.8 & 4.2 & 5.5 & 3.4 \\
\hline & & Maximum & 5.9 & 3.3 & 6.1 & 4.3 & 6.2 & 4.9 & 6.7 & 5.3 & 6.6 & 4.6 \\
\hline & Piceance Creek & $\mathrm{n}$ & & & 1 & 1 & 1 & 1 & 1 & 1 & 3 & 3 \\
\hline & & Mean & & & 5.6 & 3.4 & 5.4 & 4.1 & 6.2 & 4.9 & 6.6 & 4.3 \\
\hline & & SD & & & & & & & & & 0.2 & 0.3 \\
\hline & & SE & & & & & & & & & 0.1 & 0.2 \\
\hline & & Minimum & & & & & & & & & 6.4 & 4.0 \\
\hline & & Maximum & & & & & & & & & 6.7 & 4.6 \\
\hline
\end{tabular}

low is based solely on Thewissen's (1990) referral of USNM 20736, a partial skull with nearly complete left and right dentaries (Figure 7.4). USNM 20736 was originally described and illustrated by Gazin (1956), who assigned it to E."ralstonensis" Granger, 1915 and distinguished it from Wasat- chian aged E. osbornianus in the USNM collections based on the slightly smaller size and less molariform p3 and p4. This assignment, however, was made without the recognition that E."ralstonensis" had been made a chronologically-constrained subspecies of $E$. osbornianus by Simpson 
(1937). Assignment of USNM 20736 to E. osbornianus was followed by Dorr and Gingerich (1980, table 2), who clearly identified the specimen as coming from the Clarkforkian, rather than Tiffanian, part of the Chappo Member of the Wasatch Formation. Later, Thewissen (1990) assigned USNM 20736 to $E$. mediotuber based in part on the same premolar size differences noted by Gazin (1956). However, the referral is also almost certainly based upon a mistaken assumption that the specimen was Tiffanian in age, as Thewissen (1990, 1992) clearly articulated the notion that $E$. mediotuber is a time-constrained species lacking apomorphies present in younger E. osbornianus and having few distinguishing features beyond population level proportional differences in premolar size and cusp expression. As noted by Dorr and Gingerich (1980) and confirmed by us, USNM 20736 was in fact recovered from the Clarkforkian portion of those sections.

UCMP 173401 (Figure 7.3) is a right dentary that resembles both E. osbornianus and E. mediotuber: the molars are subquadrate in occlusal outline, the paraconid is closely appressed to the metaconid and nearly indistinct from the paracristid, the metaconid is inflated, and the hypoconulid and entoconid are closely approximated. UCMP 173493 is similar in morphology, but more worn. These specimens fall within the overlapping size range of $E$. osbornianus and $E$. mediotuber and are slightly larger than the specimens assigned to E. parvus from the Piceance Creek Basin (Table 5). Based on current nomenclature of Ectocion species, UCMP 173401 and 173493 and USNM 20736 are consistent with the diagnoses of $E$. osbornianus and are assigned to that species.

\section{DISCUSSION}

Notable additions to the Buckman Hollow fauna are the first record of Neoliotomus conventus, the most southerly record of the creodont Dipsalidictis and the mesonychian Dissacus praenuntius, and the identification of a specimen close to or belonging to the rare phenacodontid species Ectocion major (definitely known from just 16 specimens elsewhere). Although the new records presented here are few, their description provides an opportunity to revisit latest Paleocene mammalian biogeography and biostratigraphy beyond the wellstudied Bighorn Basin fauna. Anemone and Dirks (2009) previously emphasized the limited sampling of late Paleocene faunas across North America and problem of differences in documented ranges in different areas (i.e., anachronistic taxa or unusual co-occurrences of taxa). The recent identification of Ectocion parvus in the Clarkforkian of the Piceance Creek Basin in Colorado (Burger, 2012), a taxon traditionally thought to first appear in the Bighorn Basin during the earliest Eocene, provides additional impetus for careful reconsideration of late Paleocene faunas. Burger (2012) hypothesized that the northward shift of this taxon occurred due to warming climate; however, it is also interesting to consider the early appearance of Ectocion parvus in terms of faunal anachronism or unexpected taxonomic co-occurrences in the latest Paleocene, an issue explicitly raised by Anemone and Dirks (2009) in their consideration of Mark's Locality.

Anachronism, by definition, implies that there is a correct ordering or juxtaposition of occurrences within a time interval, and the idea that faunas can be ordered in time is the foundation of biozonation and biochronology. It should be remembered, however, that any biozonation is a hypothesis of the succession of faunas with respect to a chronology. The Clarkforkian Land Mammal Age is conventionally divided into three numbered biozones, based on faunal succession within the Bighorn Basin (e.g., Gingerich, 1976, 2001; Rose, 1981; Archibald et al., 1987; Lofgren et al., 2004). The early Clarkforkian (Cf1) is an interval zone (i.e., a zone bounded by two distinct biostratigraphic horizons or events), which is bounded by the first appearance of Rodentia at the base and the first appearance of Plesiadapis cookei at the top. The middle Clarkforkian (Cf2) was originally envisioned as the range zone (i.e., a zone defined by the range of a selected taxon) of P.cookei (Gingerich, $1976,2001)$ but has been revised to an interval zone by Secord et al. (2006), whose top is marked by the first appearance of the phenacodontid condylarth Copecion. Traditionally, the latest Clarkforkian (Cf3) was characterized as an abundance or acme zone (i.e., a zone defined high relative abundance of selected taxa) of Phenacodus and Ectocion, but has now also been revised as an interval zone.

By both past and current definitions of the subdivisions of the Clarkforkian, virtually all Clarkforkian faunas outside the Bighorn Basin are Cf2 in age, based on the presence of Plesiadapis cookei (whether in the interval or range zone context). Nonetheless, many authors have applied assemblage or concurrent-range zone (i.e., zones recognized by the joint occurrence of selected taxa) methods in an attempt to better correlate Clarkforkian faunas by using taxa that are not part of any 
TABLE 5. Chart comparing current faunal lists for Clarkforkian faunas of southwestern Wyoming and northern Colorado. Solid circles indicate taxa referred to a fauna based on figured or published voucher specimens; open circles indicate taxa known only from faunal lists. Primary references for each locality are as follows: 1) Buckman Hollow - Gazin 1942, 1956; Dorr and Gingerich, 1980; Rose 1981, Gingerich 1976, Thewissen 1990; this paper; 2) Piceance Creek Clarkforkian composite - Patterson, 1933, 1934, 1937, 1939; Patterson and West, 1973; Kihm, 1984; Lucas, 1998; Burger and Honey, 2008; Burger, 2012; 3) Great Divide Basin - Anemone and Dirks, 2009; 4) Big Multi Quarry - Wilf et al., 1998; Dawson and Beard, 1996; Chester and Beard, 2012; 5) Togwotee Pass or lower variegated sequence Cf composite fauna in Purdy Basin - McKenna, 1980; Rose, 1981.

\begin{tabular}{|c|c|c|c|c|c|c|}
\hline & & $\begin{array}{c}\text { Buckman } \\
\text { Hollow }\end{array}$ & $\begin{array}{l}\text { Piceance Creek } \\
\text { Clarkforkian } \\
\text { composite }\end{array}$ & $\begin{array}{c}\text { Great } \\
\text { Divide } \\
\text { Basin }\end{array}$ & Big Multi & $\begin{array}{c}\text { Purdy Basin } \\
\text { Cf }\end{array}$ \\
\hline \multicolumn{7}{|l|}{ Multituberculata } \\
\hline Eucosmodontidae & Neoliotomus conventus & $\bullet$ & $\circ$ & - & $\circ$ & - \\
\hline Microcosmodontidae & Microcosmodon conus & - & - & - & $\bullet$ & - \\
\hline Neoplagiaulacidae & Parectypodus sp. & - & - & $\circ$ & $\bullet$ & - \\
\hline Neoplagiaulacidae & Ectypodus sp. & - & - & - & $\bullet$ & - \\
\hline Ptilodontidae & Prochetodon sp. & $\bullet$ & $\circ$ & $\circ$ & - & - \\
\hline \multicolumn{7}{|l|}{ Marsupialia } \\
\hline Didelphidae & Peradectes sp. & - & - & $\circ$ & $\circ$ & - \\
\hline \multicolumn{7}{|l|}{ Arctostylopida } \\
\hline Arctostylopidae & Arctostylops steini & - & - & - & - & $\circ$ \\
\hline \multicolumn{7}{|l|}{ "Condylarthra" } \\
\hline Arctocyonidae & Anacodon nexus & $\bullet$ & - & - & - & $\circ$ \\
\hline Arctocyonidae & Lambertocyon ischyrus & - & $\circ$ & - & - & \\
\hline Arctocyonidae & Chriacus sp. & - & - & - & $\circ$ & $\circ$ \\
\hline Oxyclaenidae & Thryptacodon sp. & $\circ$ & $\circ$ & $\circ$ & - & - \\
\hline Phenacodontidae & Ectocion osbornianus & $\bullet$ & $\circ$ & $\circ$ & $\circ$ & $\bullet$ \\
\hline Phenacodontidae & Ectocion parvus & - & $\bullet$ & - & - & $\circ$ \\
\hline Phenacodontidae & Ectocion major & $\mathrm{cf}$ & $\bullet$ & - & - & - \\
\hline Phenacodontidae & Phenacodus intermedius & $\bullet$ & $\circ$ & $\circ$ & $\circ$ & $\bullet$ \\
\hline Phenacodontidae & Phenacodus vortmani & $\bullet$ & $\circ$ & $\circ$ & - & $\circ$ \\
\hline Apheliscidae & Haplomylus simpsoni & - & $\circ$ & - & - & $\bullet$ \\
\hline Apheliscidae & Apheliscus nitidus & $\bullet$ & - & $\circ$ & $\circ$ & $\bullet$ \\
\hline Apheliscidae & Aletodon sp. & - & - & - & $\circ$ & $\circ$ \\
\hline \multicolumn{7}{|l|}{ Creodonta } \\
\hline Oxyaenidae & Oxyaena transiens & - & - & - & - & $\circ$ \\
\hline Oxyaenidae & Oxyaena platypus & - & - & - & - & $\circ$ \\
\hline Oxyaenidae & Dipsalidictis krausei & $\bullet$ & - & - & - & - \\
\hline Hyaenodontidae & cf. Prolimnocyon atavus & - & - & - & - & $\circ$ \\
\hline Hyaenodontidae & ?Dipsalodon matthewi & - & - & - & - & $\bullet$ \\
\hline Hyaenodontidae & Dipsalodon n. sp. & - & - & - & - & $\bullet$ \\
\hline \multicolumn{7}{|l|}{ Dinocerata } \\
\hline Prodinoceratidae & Probathyopsis harrisorum & $\bullet$ & $\bullet$ & - & $\circ$ & - \\
\hline \multicolumn{7}{|l|}{ Mesonychia } \\
\hline Mesonychidae & Dissacus navajovius & $\bullet$ & $\circ$ & - & - & $\circ$ \\
\hline \multicolumn{7}{|l|}{ Palaeanodonta } \\
\hline Epoicotheriidae & Palaeanodon cf. parvulus & & - & - & $\circ$ & - \\
\hline \multicolumn{7}{|l|}{ Cimolesta } \\
\hline Barylambdidae & Barylambda faberi & $\bullet$ & $\bullet$ & - & - & - \\
\hline
\end{tabular}


HOLROYD \& RANKIN: BUCKMAN HOLLOW LOCAL FAUNA

TABLE 5 (continued).

\begin{tabular}{|c|c|c|c|c|c|c|}
\hline & & $\begin{array}{c}\text { Buckman } \\
\text { Hollow }\end{array}$ & $\begin{array}{c}\text { Piceance Creek } \\
\text { Clarkforkian } \\
\text { composite }\end{array}$ & $\begin{array}{c}\text { Great } \\
\text { Divide } \\
\text { Basin }\end{array}$ & Big Multi & $\begin{array}{c}\text { Purdy Basin } \\
\text { Cf }\end{array}$ \\
\hline Coryphodontidae & Coryphodon & - & - & - & - & $\circ$ \\
\hline Cyriacotheriidae & $\begin{array}{l}\text { Cyriacotherium } \\
\text { psamminum }\end{array}$ & - & - & - & $\circ$ & - \\
\hline Titanoideidae & Titanoides primaevus & - & $\circ$ & - & - & - \\
\hline \multicolumn{7}{|l|}{ Pantolesta } \\
\hline Pantolestidae & Palaeosinopa sp. & - & - & - & $\circ$ & $\circ$ \\
\hline \multicolumn{7}{|l|}{ Proteutheria } \\
\hline Palaeoryctidae & Palaeoryctes cf. punctatus & - & - & - & $\circ$ & - \\
\hline \multicolumn{7}{|l|}{ Carnivora } \\
\hline Viverravidae & Protictis proteus & - & $\circ$ & - & - & $\circ$ \\
\hline Viverravidae & Viverravus sp. & $?$ & - & - & $\circ$ & $\bullet$ \\
\hline Viverravidae & Didymictis sp. & $\bullet$ & - & $\circ$ & $\circ$ & $\circ$ \\
\hline \multicolumn{7}{|l|}{ Dermoptera } \\
\hline & Planetetherium sp. & - & - & - & $\circ$ & $\bullet$ \\
\hline \multicolumn{7}{|l|}{ Primates } \\
\hline Microsyopidae & Arctodontomys sp. & - & - & - & $\circ$ & - \\
\hline Microsyopidae & $\begin{array}{l}\text { Arctodontomys } \\
\text { simplicidens }\end{array}$ & - & - & - & $\circ$ & - \\
\hline Plesiadapidae & Chiromyoides caesor & - & $\bullet$ & - & $\circ$ & - \\
\hline Plesiadapidae & Plesiadapis dubius & $\bullet$ & $\bullet$ & $\bullet$ & $\circ$ & $\circ$ \\
\hline Plesiadapidae & Plesiadapis cookei & $\bullet$ & - & $\bullet$ & $\circ$ & $\circ$ \\
\hline Plesiadapidae & cf. Plesiadapis & - & - & $\bullet$ & - & - \\
\hline Paromomyidae & Phenacolemur cf. pagei & - & - & $\bullet$ & $\circ$ & $\circ$ \\
\hline Paromomyidae & Phenacolemur cf. simonsi & - & - & - & $\circ$ & - \\
\hline Paromomyidae & cf. Ignacius sp. & - & - & - & $\circ$ & - \\
\hline Carpolestidae & Carpolestes nigridens & $\bullet$ & - & $\bullet$ & $\circ$ & $\circ$ \\
\hline Micromomyidae & Dryomomys dulcifer & - & - & - & $\bullet$ & - \\
\hline Micromomyidae & Tinimomys tribos & - & - & - & $\bullet$ & - \\
\hline \multicolumn{7}{|l|}{ Lipotyphla } \\
\hline Erinaceidae & Diacocherus minutus & - & - & $\circ$ & $\circ$ & - \\
\hline Erinaceidae & Leipsanolestes & - & - & - & $\circ$ & $\bullet$ \\
\hline Nyctitheriidae & Ceutholestes sp. & - & - & - & $\circ$ & - \\
\hline Nyctitheriidae & Limaconyssus sp. & - & - & - & $\circ$ & - \\
\hline Nyctitheriidae & Wyonycteris sp. & - & - & - & $\circ$ & - \\
\hline Nyctitheriidae & Plagioctenodon sp. & - & - & $\circ$ & $\circ$ & - \\
\hline \multicolumn{7}{|l|}{ Rodentia } \\
\hline Ischyromyidae & Paramys adamus & $\bullet$ & - & $\circ$ & $\bullet$ & - \\
\hline Ischyromyidae & P. cf. P. atavus & - & - & - & - & $\circ$ \\
\hline Ischyromyidae & P. cf. P. excavatus & - & - & - & - & $\circ$ \\
\hline Alagomyidae & Alagomys russelli & - & - & - & $\bullet$ & - \\
\hline \multicolumn{7}{|l|}{ Taeniodonta } \\
\hline Stylinodontidae & Ectoganus gliriformis & $\bullet$ & $\circ$ & - & - & $\circ$ \\
\hline \multicolumn{7}{|l|}{ Tillodonta } \\
\hline Esthonychidae & Azygonyx xenicus & - & - & - & $\circ$ & $\bullet$ \\
\hline
\end{tabular}


zone definition. Wilf et al. (1998) argued that Big Multi Quarry was Cf1 and early but not earliest Clarkforkian based on the joint occurrence of Microcosmodon conus and Planetetherium (unknown from other Cf2 strata), the presence of Carpolestes nigridens, and species of Chiromyoides and Aletodon thought to be more primitive than typical Cf2 representatives of those genera. Lofgren et al. (2004) suggested that part of the Piceance Creek Basin sequence might also be referable to Cf3 based on the presence of a species of Phenacolemur. Anemone and Dirks (2009) extensively discussed the possible relevance of plesiadapid and carpolestid primate species in understanding the biochronology of Mark's Locality. The operational use of assemblage zone or concurrent-range zone biostratigraphic methods is also evident in the explicit attempts of Archibald et al. (1987) and Lofgren et al. (2004) to note characteristic or other index taxa for the three numbered Clarkforkian zones. Within systematic works, the potential biostratigraphic utility of some taxa also has been noted, e.g., Bloch and Gingerich (1998) suggested that Carpolestes nigridens is a useful biostratigraphic indicator taxon for the earliest Clarkforkian.

The use of the Clarkforkian numbered zones as range zones is consistent with their original definition and with standard biostratigraphic practice. The practice of using these range zone terms when correlating using assemblage zone or concurrent range zone methods is tempting but is not good biostratigraphic practice. Using the Clarkforkian numbered zones in any context except as a range zone should be avoided, since it promotes confusion about whether the presence or absence of a taxon in an assemblage or zone is "anachronistic" and diminishes the utility of the interval zone concept. However, the fact that so many researchers attempt to employ assemblage or concurrentrange zone biostratigraphic methods in many studies of Clarkforkian faunas, especially those outside the Bighorn Basin, highlights the problems of trying to correlate between well-characterized and wellsampled stratigraphic sections, where interval zones based on a small number of taxa may be practicable, with sites or sections that are less complete.

For the Clarkforkian, it is clear that the development of explicit assemblage zone or concurrent range zones would be a useful direction for future research in order to clarify or improve the biostratigraphic sequencing of taxa and rocks in sections where other data are lacking. Simply using the interval zones as developed in the Bighorn Basin only permits us to assign them to a somewhat coarse interval of time without hope of putting them in a more refined seriation. As clearly stated in the North American Stratigraphic Code (NACSN, 1983, 2005) and the International Stratigraphic Guide (ISSC, 1994) assemblage or concurrent range zones can easily exist side by side with interval zones and can provide useful adjunct data to better refine the age of rocks and the faunas they contain. Rather than continuing attempts to adapt interval zones into some modified assemblage or concurrent range zone (as done by Lofgren et al., 2004), it would be more effective to develop a broader taxonomic coverage of biostratigraphically useful taxa.

Nonetheless, developing a more taxonomically-broad biostratigraphic framework is potentially challenging. For the latest Paleocene, the geographic sampling of this time period (i.e., the Bighorn Basin, and only a handful of localities in southwestern Wyoming and Colorado) is so poor that the most common pattern of faunal co-occurrence in largely unknown. It is critical to remember that, in contrast to many other taxa used in biostratigraphy, the geographic ranges of these Paleocene mammals are among the least well characterized in the entire Cenozoic record. Localities from a broader geographic range, even if not in long, well-constrained stratigraphic sections provide an opportunity to test ideas about taxon cooccurrence.

Aside from these findings, we concur with Anemone and Dirks (2009) that the ordering of individual faunal elements seen in the Bighorn Basin might not be a useful guide for biochronology in the southern basins. There is increasing evidence that from at least the Late Cretaceous and through the Paleocene of North America that both north- and southward range shifts occur within the faunal and floral communities of the region (e.g., Holroyd et al., 2001; Holroyd and Hutchison, 2002 for turtles; Smith, 2009 for lizards; Wing et al., 2005 for flora from megaflora and pollen). In many cases where taxa appear abruptly at higher latitudes due to a dispersal event originating from the lower latitudes, these taxa may come from long-lived lineages endemic to the southern areas. Thus, their use as biostratigraphic indicators will only be effective within a limited latitudinal band and one would expect their stratigraphic ranges in more northerly areas to be shorter than in the area from which they dispersed. We should entertain the possibility that the ranges of some mammals in the Bighorn 
Basin may be shorter than in other places. For example, if we consider geographic range an important criterion in determining whether cooccurrences are "normal" or "anachronistic" then the widespread co-occurrence of Plesiadapis cookei and $P$. dubius should probably be considered the norm.

In order to better facilitate comparison of taxon occurrences, Table 5 provides updated faunal lists for Clarkforkian faunas outside the Bighorn Basin. For each taxon, we also indicate whether the record is based on published (vouchered or illustrated) specimens or unvouchered faunal lists. It is likely that closer examination of some of these faunas will reveal the presence of additional (especially rarer) taxa that are shared.

Buckman Hollow differs from nearby faunas in the very low numbers of small-bodied taxa. This lack of small specimens is likely a taphonomic effect. The Chappo Member of the Wasatch Formation itself is characterized by conglomeratic oxidized sediments (Oriel, 1962), and many of the specimens show significant post-deposition diagenetic alteration, including enamel and bone degradation (e.g., Figure 7.4). Focusing on taxa shared rather than lacking, Buckman Hollow appears to share the greatest similarities with the Piceance Creek Basin, with 14 taxa occurring within both faunas. Other Clarkforkian faunas share slightly fewer taxa, including Big Multi Quarry and Mark's Locality which both share 11 taxa with Buckman Hollow, and the Purdy Basin fauna with 10 taxa in common with Buckman Hollow. It is difficult, however, to evaluate the confidence of these comparisons, as the difference in taxa shared might simply reflect the degree to which the faunas have been studied.

Currently, comparisons among Clarkforkian assemblages outside the Bighorn Basin must principally be accomplished through faunal lists. With the exception of the Buckman Hollow local fauna, only the assemblage from the Piceance Creek Basin contains vouchered specimens for at least half of the taxa. Big Multi Quarry and Mark's Locality have been the subject of preliminary faunal reports (Wilf et al., 1998; Anemone and Dirks, 2009) and formal description of select aspects of the fauna (Dawson and Beard, 1996; Anemone and Dirks, 2009; Chester and Beard, 2012), while the Togwotee Pass/Purdy Basin fauna is the most poorly known, with vouchered specimens only appearing in text discussions and table footnotes in the treatment of the Clarkforkian presented by Rose (1981) and systematic works on phenaco- dontids (West, 1976; Thewissen, 1990). As a consequence, morphological comparisons among rare Clarkforkian species and fossil specimens are difficult and attempts to clarify changes in taxonomy are challenging.

Lack of basic specimen-level data also hampers our ability to effectively test most of the hypotheses that come from comparisons of the faunal data. Key examples are the important and rather vexing phenacodontid condylarths. Widespread and common in the Paleocene, most of the prior work has focused upon their stratigraphic and biogeographic distribution within the Bighorn Basin and using the ample sample sizes found there to document evolutionary trends in the dentition. As a consequence, however, comparatively few studies have provided details on the size and morphological details of individual specimens or even groups of specimens from geographically constrained areas, but usually only summary data (e.g., West, 1976; Thewissen, 1990). Ectocion parvus is a case in point. Thewissen (1990) reported that McKenna (1980) had listed E. parvus present at Togwotee Pass, but had not examined the specimens. Rose (1981) noted that West (1976) listed two specimens (AMNH 57208 and 57286) as E. parvus from Togwotee Pass and suggested that they were small representatives of E. osbornianus. It is difficult to assess how new data may impact these assessments, as no specimen level measurement or morphologic data have been published for the Togwotee Pass faunas.

In addition to providing new data on the Buckman Hollow local fauna, we hope our study highlights the need to better understand and characterize these Paleocene faunas of the basins of southern Wyoming and northern Colorado. Work by Burger (2012) illustrates the possibility of making direct connections between taxa that appear during the Paleocene-Eocene boundary interval in locations further north and the need to more explicitly address to what extent dispersals are from neighboring regions (e.g., other intermontane basins of the Rocky Mountain region) or those that are thought to have come from even further south based on yet untested hypotheses about their distributions. Other possible dispersers of southern origin include a number of non-mammalian taxa (e.g., lizards [Smith, 2009], some turtles [Holroyd et al., 2001; Bourque et al., 2008], and plants [Harrington, 2001]). Identification of all possible withincontinent migrant taxa and joint study of these may permit us to assess possible temperature-related phenomena that may have affected dispersal 
potential differently in heterotherms and homeotherms.

\section{ACKNOWLEDGMENTS}

We thank D. Strauss for photography of many UCMP specimens, and S. Saroka for assistance in constructing figures. Figure 1 is based on the public domain Physical Map of the Coterminous United States by T. Patterson. For access to comparative and primary collections, we thank $C$. Norris and D. Brinkman (YPM), M. Brett-Surman, R. Emry, and N.D. Pyenson (USNM), G.F. Gunnell and P.D. Gingerich (UM). Fieldwork by PAH in Buckman Hollow was conducted with $\mathrm{J}$. Howard Hutchison under Bureau of Land Management permit 302-WY-PA94 and with support from the Annie M. Alexander Endowment of the UCMP. Work by BDR at UCMP was supported by an Alexander Graham Bell Canada Graduate Scholarship and Michael Smith Foreign Studies Supplement from NSERC of Canada.

\section{REFERENCES}

Anemone, R.L. and Dirks, W. 2009. An anachronistic Clarkforkian mammal fauna from the Paleocene Fort Union Formation (Great Divide Basin, Wyoming, USA). Geologica Acta, 7:113-124.

Archibald, J.D., Clemens, W.A., Gingerich, P.D., Krause, D.W., Lindsay, E.H., and Rose, K.D. 1987. First North American land mammal ages of the Cenozoic era, p. 24-76. In Woodburne, M. (ed.), Cenozoic Mammals of North America. University of California Press, Berkeley.

Bloch, J.I. and Gingerich, P.D. 1998. Carpolestes simpsoni, new species (Mammalia, Proprimates) from the late Paleocene of the Clark's Fork Basin, Wyoming. The University of Michigan, Contributions from the Museum of Paleontology, 30:131-162.

Bourque, J., Hutchison, J.H., Holroyd, P.A., and Bloch, J.I. 2008. A new kinosternoid (Testudines: Dermatemydidae) from the Paleocene-Eocene boundary of the Bighorn Basin, Wyoming, and its paleoclimatological implications. Journal of Vertebrate Paleontology, 28:55A.

Burger, B.J. 2012. Northward range extension of a diminutive-sized mammal (Ectocion parvus) and the implication of body size change during the PaleoceneEocene Thermal Maximum. Palaeogeography, Palaeoclimatology, Palaeoecology, 363-364:144150.

Burger, B.J. and Honey, J.G. 2008. Plesiadapidae (Mammalia, Primates) from the late Paleocene Fort Union Formation of the Piceance Creek Basin, Colorado. Journal of Vertebrate Paleontology, 28:816-825.
Chester, S.G.B. and Beard, K.C. 2012. New micromomyid plesiadapiforms (Mammalia, Euarchonta) from the late Paleocene of Big Multi Quarry, Washakie Basin, Wyoming. Annals of Carnegie Museum, 80:159-172.

Cope, E.D. 1873a. On the short-footed Ungulata of the Eocene of Wyoming. Proceedings of the American Philosophical Society, 13:38-74.

Cope, E.D. 1873b. Fourth notice of extinct Vertebrata from the Bridger and Green River Tertiaries. Paleontological Bulletin, 17:1-4.

Cope, E.D. 1875. Systematic catalogue of Vertebrata of the Eocene of New Mexico collected in 1874. Geographical Explorations and Surveys West of the $100^{\text {th }}$ Meridian, First Lieutenant Geo. M. Wheeler, Corps of Engineers, United States Army, Corps of Engineers, Washington, 1985:5-37.

Cope, E.D. 1877. Report upon the extinct Vertebrata obtained in New Mexico by parties of the expedition of 1874. Geographical Explorations and Surveys West of the $100^{\text {th }}$ Meridian, First Lieutenant Geo. M. Wheeler, Corps of Engineers, United States Army, Corps of Engineers. Volume IV. - Paleontology. Part III. Washington 1987:1-370.

Cope, E.D. 1880. The badlands of the Wind River and their fauna. American Naturalist, 14:745-748.

Cope, E.D. 1881. A new type of Perissodactyla. American Naturalist, 15:1017-1020.

Cope, E.D. 1882a. Notes on Eocene Mammalia. American Naturalist, 16:522.

Cope, E.D. 1882b. Contributions to the history of Vertebrata of the lower Eocene of Wyoming and New Mexico, made during 1881. Proceedings of the American Philosophical Society, 34:139-191.

Cope, E.D. 1883. The ancestor of Coryphodon. American Naturalist, 17:406-407.

Cope, E.D. 1884. The Tertiary Marsupialia. American Naturalist, 18:686-697.

Dawson, M.R. and Beard, K.C. 1996. New late Paleocene rodents (Mammalia) from Big Multi Quarry, Washakie Basin, Wyoming. Palaeovertebrata, 25:301-321.

Dorr, J.A. and Gingerich, P.D. 1980. Early Cenozoic mammalian paleontology, geologic structure, and tectonic history in the overthrust belt near LaBarge, Wyoming. University of Wyoming Contributions to Geology, 18:101-115.

Flerov, K.K. 1952. New Dinocerata from Mongolia. Doklady Akademia Nauk S. S. R., 86:1029-1032. (Translated from Russian)

Gazin, C.L. 1942. Fossil Mammalia from the Almy Formation in western Wyoming. Journal of the Washington Academy of Sciences, 32:217-220.

Gazin, C.L. 1956. The upper Paleocene Mammalia from the Almy Formation in western Wyoming. Smithsonian Miscellaneous Collections, 131:1-18. 
Gervais, P. 1877. Énumération de quelques ossements d'animaux vertébrés recueillis aux environs de Reims par M. Lemoine. Journal de Zoologie, Paris, 6:74-79.

Gill, T. 1872. Arrangement of the families of mammals with analytical tables. Smithsonian Miscellaneous Collections, 11:1-98.

Gingerich, P.D. 1976. Cranial anatomy and evolution of early Tertiary Plesiadapidae (Mammalia, Primates). The University of Michigan Papers on Paleontology, 15:1-140.

Gingerich, P.D. 2001. Biostratigraphy of the continental Paleocene-Eocene boundary interval on Polecat Bench in the northern Bighorn Basin. University of Michigan Papers on Paleontology, 33:37-71.

Gingerich, P.D. and Childress, C.G., Jr. 1983. Barylambda churchilli, a new species of Pantolambdidae (Mammalia, Pantodonta) from the late Paleocene of western North America. Contribution from the Museum of Paleontology, The University of Michigan, 26:141-155.

Granger, W. 1915. Part III: Order Condylarthra. Families Phenacodontidae and Meniscotheriidae, In Matthew, W.D. and Granger, W. (auths.), A revision of the lower Eocene Wasatch and Wind River faunas. Bulletin of the American Museum of Natural History, 34:4-103.

Granger, W. and Simpson, G.G. 1928. Multituberculates in the Wasatch Formation. American Museum Novitates, 312:1-4.

Gregory, W.K. 1910. The orders of mammals. Bulletin of the American Museum of Natural History, 27:1-254.

Gunnell, G.F. 1994. Paleocene mammals and faunal analysis of the Chappo Type Locality (Tiffanian), Green River Basin, Wyoming. Journal of Vertebrate Paleontology, 14:81-104.

Gunnell, G.F. and Gingerich, P.D. 1991. Systematics and Evolution of late Paleocene and early Eocene Oxyaenidae (Mammalia, Creodonta) in the Clarks Fork Basin, Wyoming. Contributions from the Museum of Paleontology, The University of Michigan, 28:141180.

Harrington, G. 2001. Pollen assemblages and Paleocene-Eocene stratigraphy in the Bighorn and Clarks Fork Basins. The University of Michigan Papers on Paleontology, 33:89-96.

Holroyd, P.A. and Hutchison, J.H. 2002. Patterns of geographic variation in latest Cretaceous vertebrates: evidence from the turtle component. Geological Society of America Special Paper, 361:177-190.

Holroyd, P.A., Hutchison, J.H., and Strait, S.G. 2001. Turtle diversity and abundance through the lower Eocene Willwood Formation of the southern Bighorn Basin. The University of Michigan Papers on Paleontology, 33:97-107.

Hutchison, J.H. 2013. New turtles from the Paleogene of North America, p.477-497. In Brinkman, D.B, Holroyd, P.A., and Gardner, J.D. (eds.), Morphology and Evolution of Turtles. Springer, Netherlands.
ISSC. 1994. International stratigraphic guide: a guide to stratigraphic classification, terminology, and procedure: Trondheim, Boulder, The International Union of Geological Sciences and the Geological Society of America, $214 \mathrm{p}$.

Jepsen, G.L. 1930. Stratigraphy and paleontology of the Paleocene of northeastern Park County, Wyoming. Proceedings of the American Philosophical Society, 69:463-528.

Kihm, A.J. 1984. Early Eocene mammalian faunas of the Piceance Creek Basin, northwestern Colorado. Ph.D. thesis. University of Colorado at Boulder, Boulder, Colorado.

Krause, D.W. 1980. Multituberculates from the Clarkforkian Land-Mammal Age, late Paleocene-early Eocene, of western North America. Journal of Paleontology, 54:1163-1183.

Krause, D.W. 1982. Multituberculates from the Wasatchian Land-Mammal Age, early Eocene, of western North America. Journal of Paleontology, 54:271-294.

Krause, D.W. 1987. Systematic revision of the genus Prochetodon (Ptilodontidae, Multituberculata) from the late Paleocene and early Eocene of western North America. Contributions from the Museum of Paleontology, The University of Michigan, 27:221236.

Linnaeus, C. 1758. Systema naturae per regna tria naturae, secundum classes, ordines, genera, species cum characteribus, differentiis, synonymis, locis. Tomus I: Regnum animale. Editio decima, reformata. Laurentii Salvii, Stockholm [Facsimile reprinted in 1956 by the British Museum of Natural History].

Linnaeus, C. 1766. Systema naturae per regna tria naturae, secundum classes, ordines, genera, species cum characteribus, differentiis, synonymis, locis. Tomus I: Regnum animale. Editio decima, reformata. Laurentii Salvii, Stockholm [12 ${ }^{\text {th }}$ edition].

Lofgren, D.L., Lillegraven, J.A., Clemens, W.A., Gingerich, P.D., and Williamson, T.E. 2004. Paleocene biochronology: the Puercan through Clarkforkian Land Mammal Ages, p. 43-105. In Woodburne, M. (ed.), Late Cretaceous and Cenozoic Mammals of North America: Biostratigraphy and Geochronology. Columbia University Press, New York.

Lucas, S.G. 1998. Fossil mammals and the Paleocene/ Eocene Series boundary in Europe, North America, and Asia, p. 451-500. In Aubry, M.-P (ed.), Late Paleocene-early Eocene climatic and biotic events in the marine and terrestrial records. Columbia University Press, New York.

Marsh, O.C. 1872. Notice of some remarkable fossil mammals. American Journal of Science, 4:343-344.

Marsh, O.C. 1880. Notice of Jurassic mammals representing two new orders. American Journal of Science, 11:425-428. 
Matthew, W.D. 1915a. Part I: Order Ferae (Carnivora), Suborder Creodonta. In W.D. Matthew and W. Granger (auths.), A revision of the lower Eocene Wasatch and Wind River faunas. Bulletin of the American Museum of Natural History, 34:4-103.

Matthew, W.D. 1915b. Part IV: Entelonychia, Primates, Insectivora (Part). In Matthew, W.D. and Granger, W. (auths.), A revision of the lower Eocene Wasatch and Wind River faunas. Bulletin of the American Museum of Natural History 34:429-483.

Matthew, W.D. 1937. Paleocene faunas of San Juan Basin, New Mexico. Transactions of the American Philosophical Society, 30:1-510.

McKenna, M.C. 1960. Fossil Mammalia from the early Wasatchian Four Mile fauna, Eocene of northwest Colorado. The University of California Publications in Geological Sciences, 37:1-130.

McKenna, M.C. 1975. Towards a phylogenetic classification of the Mammalia, p. 21-46. In Luckett, W.P. and Szalay, F.S. (eds.), Phylogeny of the Primates: $A$ Multidisciplinary Approach. Plenum Press, New York.

McKenna, M.C. 1980. Late Cretaceous and early Tertiary vertebrate paleontological reconnaissance, Togwotee Pass area, northwestern Wyoming, p. 323-343. In Jacobs, L.L (ed.), Aspects of Vertebrate History: Essays in Honor of Edwin Harris Colbert. Museum of Northern Arizona Press, Flagstaff, Arizona.

NACSN. 1983. North American Stratigraphic Code, North American Commission on Stratigraphic Nomenclature. American Association of Petroleum Geologists Bulletin, 67:841-875.

NACSN. 2005. North American Stratigraphic Code, North American Commission on Stratigraphic Nomenclature. American Association of Petroleum Geologists Bulletin, 89:1547-1591.

O'Leary, M.A. and Rose, K.D. 1995. New mesonychian dentitions from the Paleocene and Eocene of the Bighorn Basin, Wyoming. Annals of the Carnegie Museum, 62:147-172.

Oriel, S.S. 1962. Main body of Wasatch Formation near LaBarge, Wyoming. American Association of Petroleum Geologists, Bulletin, 46:2161-2173.

Parker, T.J. and. Haswell W.A. 1897. A Text-book of Zoology. Volume 2. Macmillan Press, London.

Patterson, B. 1933. A new species of the ambylopod Titanoides from western Colorado. American Journal of Science, 25:415-425.

Patterson, B. 1934. A Contribution to the Osteology of "Titanoides" and the Relationships of the Amblypoda. Proceedings of the American Philosophical Society, 73:71-101.

Patterson, B. 1937. A new genus, Barylambda, for Titanoides faberi, Paleocene amblypod. Geological Series, Field Museum of Natural History, 6:229-231.

Patterson, B. 1939. New Pantodonta and Dinocerata from the upper Paleocene of western Colorado. Field Museum of Natural History, Geology Series, 6:351384.
Patterson, B. and West, R.M. 1973. A new late Paleocene phenacodont (Mammalia: Condylarthra) from western Colorado. Breviora, 403:1-7.

Rose, K.D. 1981. The Clarkforkian land-mammal age and mammalian faunal composition across the Paleocene-Eocene boundary. The University of Michigan Papers on Paleontology, 26:1-197.

Rose, K.D., Chew, A.E., Dunn, R.H., Kraus, M.J., Fricke, H.C., and Zack, S.P. 2012. Earliest Eocene mammalian fauna from the Paleocene-Eocene Thermal Maximum at Sand Creek Divide, southern Bighorn Basin. The University of Michigan Papers on Paleontology, 36:1-122.

Secord, R., Gingerich, P.D., Smith, M.E., Clyde, W.C., Wilf, P., and Singer, B.S. (2006). Geochronology and mammalian biostratigraphy of middle and upper Paleocene continental strata, Bighorn Basin, Wyoming. American Journal of Science, 306:211-245.

Simons, E.L. 1960. The Paleocene Pantodonta. Transactions of the American Philosophical Society, 50:399.

Simpson, G.G. 1929. A new Paleocene uintathere and molar evolution in Amblypoda. American Museum Novitates, 793:1-25.

Simpson, G.G. 1935. The Tiffany fauna, upper Paleocene. III. Primates, Carnivora, Condylarthra, and Amblypoda. American Museum Novitates, 817:1-28.

Simpson, G.G. 1937. Notes on the Clark Fork, Upper Paleocene, fauna. American Museum Novitates, 954:1-24.

Sloan, R.E. and Van Valen, L. 1965. Cretaceous mammals from Montana. Science, 148:220-227.

Smith, K. 2009. A new lizard assemblage from the earliest Eocene (zone Wa0) of the Bighorn Basin, Wyoming, USA: biogeography during the warmest interval of the Cenozoic. Journal of Systematic Palaeontology, 7:299-358.

Szalay, F.S. 1969. Mixodectidae, Microsyopidae, and the insectivore-primate transition. Bulletin of the American Museum of Natural History 140:195-330.

Thewissen, J.G.M. 1990. Evolution of Paleocene and Eocene Phenacodontidae (Mammalia, Condylarthra). The University of Michigan Papers on Paleontology, 29:1-107.

Thewissen, J.G.M. 1992. Temporal data in phylogenetic systematics: an example from the mammalian fossil record. Journal of Paleontology, 66:1-8.

Thewissen, J.G.M. and Gingerich, P.D. 1987. Systematics and evolution of Probathyopsis (Mammalia, Dinocerata) from the late Paleocene and early Eocene of western North America. Contributions from the Museum of Paleontology, The University of Michigan, 27:195-219.

Trousseart, E.-L. 1897. Catalogus Mammalium tam viventium quam fossilium. 1. R. Friedlander and Sohn, Berlin.

Van Valen, L. 1966. Deltatheridia, a new order of mammals. Bulletin of the American Museum of Natural History, 132:1-126. 
West, R.M. 1976. The North American Phenacodontidae (Mammalia, Condylarthra). Contributions in Biology and Geology, Milwaukee Public Museum, 6:1-78.

Wilf, P., Beard, K.C., Davies-Vollum, K.S., and Norejko, J.W. 1998. Portrait of a late Paleocene (Early Clarkforkian) terrestrial ecosystem: Big Multi Quarry and associated strata, Washakie Basin, Southwestern Wyoming. Palaios, 13:514-532.
Wing, S.L., Harrington, G.J., Smith, F.A., Bloch, J.I., Boyer, D.M., and Freeman, K.H. 2005. Transient Floral Change and Rapid Global Warming at the Paleocene-Eocene boundary. Science, 310:993-996. 